\title{
Base Excision Repair AP-Endonucleases-Like Genes Modulate DNA Damage Response and Virulence of the Human Pathogen Cryptococcus neoformans
}

\author{
Rayssa Karla de Medeiros Oliveira ${ }^{1}$, Fabián Andrés Hurtado ${ }^{1}{ }^{\circledR}$, Pedro Henrique Gomes ${ }^{1}$, Luiza Lassi Puglia ${ }^{1}$, \\ Fernanda Fonsêca Ferreira ${ }^{2}$, Kunal Ranjan ${ }^{2}{ }^{\circledR}$, Patrícia Albuquerque ${ }^{3}{ }^{\circledR}$, Márcio José Poças-Fonseca ${ }^{2, *, t}$, \\ Ildinete Silva-Pereira ${ }^{1, *,+} \mathbb{D}$ and Larissa Fernandes ${ }^{3, *,+}$
}

check for updates

Citation: Oliveira, R.K.d.M.;

Hurtado, F.A.; Gomes, P.H.; Puglia, L.L.; Ferreira, F.F.; Ranjan, K.; Albuquerque, P.; Poças-Fonseca, M.J.; Silva-Pereira, I.; Fernandes, L. Base Excision Repair

AP-Endonucleases-Like Genes Modulate DNA Damage Response and Virulence of the Human Pathogen Cryptococcus neoformans. J. Fungi 2021, 7, 133. https://doi.org/ 10.3390/jof7020133

Academic Editor: Damian J. Krysan

Received: 23 December 2020

Accepted: 5 February 2021

Published: 12 February 2021

Publisher's Note: MDPI stays neutra with regard to jurisdictional claims in published maps and institutional affiliations.

Copyright: (c) 2021 by the authors. Licensee MDPI, Basel, Switzerland. This article is an open access article distributed under the terms and conditions of the Creative Commons Attribution (CC BY) license (https:// creativecommons.org/licenses/by/ $4.0 /)$.
1 Department of Cell Biology, Institute of Biological Sciences, University of Brasília, Brasília 70.910-900, Brazil oliveirarkm@gmail.com (R.K.d.M.O.); fahejml@gmail.com (F.A.H.); pedro.hqgomes@gmail.com (P.H.G.); luiza_puglia@hotmail.com (L.L.P.)

2 Department of Genetics and Morphology, Institute of Biological Sciences, University of Brasília, Brasília 70.910-900, Brazil; fonseca.fernandaf@gmail.com (F.F.F.); kukkukr.ranjan@gmail.com (K.R.)

3 Faculty of Ceilândia, University of Brasília, Brasília 72.220-275, Brazil; palbuquerque@unb.br

* Correspondence: mpossas@unb.br (M.J.P.-F.); ildinetesp@gmail.com (I.S.-P.); larissaf@unb.br (L.F.)

$\dagger$ These authors share the senior authorship.

\begin{abstract}
Pathogenic microbes are exposed to a number of potential DNA-damaging stimuli during interaction with the host immune system. Microbial survival in this situation depends on a fine balance between the maintenance of DNA integrity and the adaptability provided by mutations. In this study, we investigated the association of the DNA repair response with the virulence of Cryptococcus neoformans, a basidiomycete that causes life-threatening meningoencephalitis in immunocompromised individuals. We focused on the characterization of $C$. neoformans APN1 and APN2 putative genes, aiming to evaluate a possible role of the predicted Apurinic/apyrimidinic (AP) endonucleases 1 and 2 of the base excision repair (BER) pathway on C. neoformans response to stress conditions and virulence. Our results demonstrated the involvement of the putative AP-endonucleases Apn1 and Apn2 in the cellular response to DNA damage induced by alkylation and by UV radiation, in melanin production, in tolerance to drugs and in virulence of $C$. neoformans in vivo. We also pointed out the potential use of DNA repair inhibitor methoxy-amine in combination with conventional antifungal drugs, for the development of new therapeutic approaches against this human fungal pathogen. This work provides new information about the DNA damage response of the highly important pathogenic fungus C. neoformans.
\end{abstract}

Keywords: Cryptococcus neoformans; base excision repair; AP-endonucleases-like genes; APN1 and APN2; virulence

\section{Introduction}

DNA integrity and genome stability are crucial for the adaptation and evolution of the species [1-3]. The ability of a pathogenic microorganism to survive in distinct environments, under different types of stresses, is usually related to phenotype plasticity. However, extreme alterations in the genome can compromise an organism's viability, so cells employ different mechanisms to preserve the genome from the mutagenic action of genotoxic agents and to ensure the correct chromosome duplication and transmission to the next generations. Molecular processes underlying genome stability include DNA damage sensors, DNA repair pathways and cell cycle checkpoints $[2,4,5]$.

DNA repair is mediated by several proteins, in a complex system of signal cascades, DNA damage sensors and effector enzymes [4,6,7]. The base excision repair (BER) pathway is responsible for the recognition and correction of non-bulky DNA lesions such as oxidized 
bases and abasic sites (AP-sites) [8,9]. The BER pathway is essential to maintain cell integrity and the organism's survival under oxidative stress.

The BER pathway involves five steps to remove the DNA lesion and to restore DNA integrity: (i) excision of a damaged or inappropriate base by glycosylase proteins; (ii) incision of the phosphodiester backbone at the resulting abasic (AP) site by AP-endonucleases (APE); (iii) termini clean-up to permit unabated repair synthesis and/or nick ligation; (iv) gap-filling to replace the excised nucleotide by DNA polymerase; and (v) sealing of the remaining DNA nick by ligase $[8,10]$. In mammals, the disruption of APE proteins blocks the entire BER pathway [11].

Two major classes of AP-endonucleases have been characterized in Escherichia coli. The Xth family (exonuclease III) is constitutive and abundant, representing about $90 \%$ of the total AP activity. The Nfo (endonuclease IV) family represents $10-50 \%$ of the AP-endonuclease activity in the cells [12-14]. AP-endonucleases may act in functions beyond the AP-site cleavage. The most extensively studied AP-endonuclease proteins are human APE1 and APE2. APE1 possesses multifunctional activity, acting as a transcription factor and a redox activator [15]. Recently, it was demonstrated that APE1 and APE2 are involved in epigenetic and chromosomal alterations, facilitating the recruitment of the transcriptional machinery to specific promoters and enabling the formation of checkpoint protein complexes [16-18].

In Saccharomyces cerevisiae Apn1 is the major AP-endonuclease and belongs to the E. coli Nfo family. S. cerevisiae Apn2 shares homology with E. coli Xth and human APE1 and APE2 and has a back-up role in the repair of AP sites when Apn1 is absent [12,19]. Both possess APE and DNA 3'-phosphodiesterase activities [20]. Unlike apn1 $\Delta$ mutants, S. cerevisiae apn $2 \Delta$ mutants exhibit normal sensitivity to the alkylating agent methyl methane-sulfonate (MMS) and show no increase in spontaneous mutation rates, suggesting a less prominent role in the repair of AP sites [12,20,21]. Studies with Candida albicans revealed that Apn1 has minor participation in the susceptibility to DNA-damaging agents and drug response [22]. The function of C. albicans Apn1 is still unclear. In Schizosaccharomyces pombe, differently from S. cerevisiae, the Apn2 protein resolves approximately $90 \%$ of the abasic lesions on the BER pathway [23]. S. pombe Apn2 is phylogenetically closer to human APE proteins and possesses important domains involved in protein-protein interactions [23,24].

The mechanisms involved in the cellular response to DNA damage and repair are of great clinical significance [25-29]. DNA damage-inducing drugs, such as cisplatin and temolozomide and DNA repair inhibitor drugs, such as methoxy-amine, are used in cancer therapy [30-32]. Several antibiotic drugs are known to cause chemical damage to DNA. Drugs from the bleomycin family bind to DNA and induce double-strand breaks [33]. Antifungal drugs, like polyenes, induce the production of reactive oxygen species (ROS) [34]. Antimicrobial-induced ROS, such as hydroxyl radicals, damage the DNA through the formation of abasic sites, DNA strand breaks, and the incorporation of oxidized guanine residues into the genome [33,35].

DNA damage and repair are also involved in microbial virulence. Mutations are involved in the microevolution of several pathogens, while pathogenic microbes have developed several mechanisms to prevent DNA damage, which can be induced, for example, by reactive oxygen, nitrogen, and chloride species during host response to infection [36-39]. C. neoformans, the etiological agent of cryptococcosis, is the major cause of illness in people living with HIV / AIDS worldwide [40,41]. This ubiquitous basidiomycete is highly adapted to extreme environmental conditions such as desiccation, high temperatures and UV exposure $[41,42]$. Considering both environmental and host-related processes that might induce DNA damage in C. neoformans cells, we decided to investigate the involvement of the BER pathway in stress resistance and virulence in this fungal pathogen by the functional characterization of the BER pathway putative genes encoding Ap-endonucleases 1 and 2. 


\section{Materials and Methods}

\subsection{Strain Maintenance}

The C. neoformans serotype A strain H99 (kindly donated by Prof. J. Andrew Alspaugh, Duke University, Durham, NC, USA) was used to generate apn1 $1 \Delta$, apn2 $2 \Delta$, the double apn $1 \Delta a p n 2 \Delta$ mutants and the complemented strains. All the strains were stored in $35 \%$ glycerol at $-80{ }^{\circ} \mathrm{C}$. Yeasts were cultured on YPD (Yeast extract - Peptone - Dextrose) agar plates ( $1 \%$ yeast extract, $2 \%$ peptone, $2 \%$ dextrose and $1.5 \%$ agar $\mathrm{pH} 5.6)$ and incubated at $30{ }^{\circ} \mathrm{C}$, unless stated otherwise. Single colonies were inoculated in liquid YPD and grown overnight at $30^{\circ} \mathrm{C}$, under agitation $(150 \mathrm{rpm})$. Before the experiments, cells were centrifuged at $4000 \mathrm{rpm}$ and washed in phosphate-buffered saline (PBS) $1 \times$ to remove the culture medium.

\subsection{Phylogenetic Analysis of the Predicted C. neoformans Apn1 and Apn2 Proteins}

The amino acid sequences of previously identified AP- endonucleases of $S$. cerevisiae (ASP85051.1), S. pombe (NP_595522.1), C. albicans (KHC89247.1), and Homo sapiens (AAD43041.1) were obtained from the Broad Institute Fungal Genome Initiative (https:/ / www.broadinstitute.org/fungal-genome-initiative, accessed on 11 February 2021), FungiDB (http:/ / fungidb.org/fungidb/, accessed on 11 February 2021) and the NCBI (National Center for Biotechnology Information) data base (https:/ /www.ncbi.nlm.nih. gov / gene, accessed on 11 February 2021). All of the sites were accessed on 5 November 2014. These sequences were compared with the genome of $C$. neoformans var grubii H99 by using the Blastp tool (https:/ / blast.ncbi.nlm.nih.gov/Blast.cgi?PAGE=Proteins, accessed on 11 February 2021). Multiple sequence alignments were performed by MUSCLE 3.7 (Multiple Sequence Comparison by Log expectation): http:/ / phylogeny.lirmm.fr/phylo_ cgi/simple_phylogeny.cgi (accessed on 11 February 2021) Task_type = muscle. From the comparison with the S. cerevisiae, C. albicans and S. pombe, CNAG_05468 and CNAG_04268 were assumed to correspond to the C. neoformans AP endonuclease 1 (Apn1) and Apn exodeoxyribonuclease III (Apn2) putative coding sequences, respectively.

\subsection{Disruption of the APN1- and APN2-Like Genes}

The $C$. neoformans APN1 and APN2 putative genes were deleted from the serotype A H99 strain background by biolistic transformation and homologous recombination of the deletion cassette. The double-joint PCR (DJ-PCR) strategy [43] was used to construct the deletion cassettes. The first round of the DJ-PCR method was performed with primer pairs to amplify the $5^{\prime}$ - and 3'-flanking regions of the target genes, using the H99 strain genomic DNA as a template. The dominant selection markers for Nourseotricin (NATr) and Hygromycin B (HYGr) were amplified with the M13Fe (M13 forward extended) and M13Re (M13 reverse extended) primers from the pPZPNAT and pPZPHYG73 plasmids, respectively. In the second round of PCR, the first-round amplicons were used as a template for the amplification of the target gene disruption cassettes with the $5^{\prime}$ or $3^{\prime}$ region of the NAT-split or HYG-split marker. The split gene disruption cassettes were introduced into the H99 strain by using the biolistic transformation method [43]. Stable Nourseothricin- or Hygromycin B- resistant transformants were screened by colony PCR with the primer sets listed in Table S1. The genotypes of all the positive transformants were verified by PCR analysis (Figure S1) and described in Table S2.

\subsection{Phenotype Assays}

For resistance to stress conditions, serial dilutions of cell suspensions $\left(10^{6}\right.$ to $10^{2}$ cells $)$ were plated on YPD agar supplemented with $0.03 \mathrm{mM}$ menadione (MND), $4 \mathrm{mg} / \mathrm{mL}$ sodium nitrite $\left(\mathrm{NaNO}_{2}\right), 1$ or $3 \mathrm{mM}$ hydrogen peroxide $\left(\mathrm{H}_{2} \mathrm{O}_{2}\right), 1.5 \mathrm{M}$ sodium chloride $(\mathrm{NaCl}), 1.5 \mathrm{M}$ potassium chloride $(\mathrm{KCl}), 32.4 \mathrm{mg} / \mathrm{mL}$ calcium sulfate $\left(\mathrm{CaSO}_{4}\right), 110 \mu \mathrm{g} / \mathrm{mL}$ hydroxyurea (HU), $0.03 \%$ ethyl methane-sulfonate (EMS), $2.5 \mathrm{M}$ sorbitol, $0.03 \%$ methyl methane-sulfonate (MMS), and 0.5 or $1 \mathrm{mg} / \mathrm{mL}$ caffeine. Plates were incubated at 30 or $37^{\circ} \mathrm{C}$ for $48 \mathrm{~h}$. For the capsule expansion measurement, cells were inoculated into 
chemically defined minimal medium ( $15 \mathrm{mM}$ dextrose, $10 \mathrm{mM} \mathrm{MgSO}$, $29.4 \mathrm{mM} \mathrm{KH} \mathrm{KO}_{4}$, $13 \mathrm{mM}$ glycine, $3 \mu \mathrm{M}$ thiamine (pH 5.5)), incubated at $30^{\circ} \mathrm{C}$, at $150 \mathrm{rpm}$, for 2 days and counterstained with India ink. The diameter of each cell body and surrounding capsule was measured by ImageJ (Fiji) software. The average diameter of the capsule was calculated by subtracting the cell body diameter from the whole cell diameter (cell body + capsule). At least 100 cells were measured for each assay.

For the analyses of phospholipase or urease activities, $10^{6}$ cells were spotted on Agar Egg emulsion medium or on Christensen's urea agar $(0.1 \%$ peptone, $0.5 \% \mathrm{NaCl}, 0.2 \%$ $\mathrm{KH}_{2} \mathrm{PO}_{4}, 0.1 \%$ glucose, $2 \%$ urea, $0.0016 \%$ phenol red), respectively, and incubated for $72 \mathrm{~h}$ at $30{ }^{\circ} \mathrm{C}$. Phospholipase activity $(\mathrm{Pz})$ was measured by the ratio of the colony diameter (DC) to the colony diameter plus precipitation zone (DCP). Pz = 1 = no activity; $1>\mathrm{Pz}>$ $0.63=$ phospholipase activity [44]. Urease activity was analyzed by the change from yellow to pink of Christensen's urea medium color.

For the melanin production assay, cells were inoculated in liquid minimal medium supplemented with $1 \mathrm{mM}$ L-DOPA (L-3,4-dihydroxyphenylalanine) (Sigma-Aldrich, St. Louis, MO, USA) and incubated at 30 or $37^{\circ} \mathrm{C}$, with shaking at $150 \mathrm{rpm}$, for 4 days in dark. All the assays were performed as three independent experiments.

\subsection{Growth Curve Analysis}

Cell suspensions were adjusted to the concentration of $1 \times 10^{5} / \mathrm{mL}$ in YPD medium. In a 96-well polystyrene microplate, $1 \times 10^{4}$ cells/well were inoculated and the plates were incubated under continuous agitation at 30 or $37^{\circ} \mathrm{C}$. Optical density was measured every $30 \mathrm{~min}$ at $600 \mathrm{~nm}$ by the Eon biotek spectrophotometer (BioTek Eon Microplate Spectrophotometers, Winooski, VT, United States) for $96 \mathrm{~h}$. All the assays were performed as three independent experiments.

\subsection{Evaluation of the Yeast Cells' Resistance to Genotoxic Stress}

For the UV irradiation susceptibility analysis, serial dilutions of cell suspensions were spotted on YPD agar plates and exposed to UV irradiation of 60 to $480 \mathrm{~J} / \mathrm{m}^{2}$ at $254 \mathrm{~nm}$ in a UV cross-linker chamber UVP CX-2000 (Fisher Scientific, Leicestershire, UK). The plates were incubated at $30^{\circ} \mathrm{C}$ for 2 days and photo-documented. For viability analyses, $5 \times 10^{2}$ cells were washed, plated on YPD plates and exposed to 120,240 or $480 \mathrm{~J} / \mathrm{m}^{2}$ at $254 \mathrm{~nm}$ in a UV cross-linker chamber. Plates were protected from light and incubated at $30^{\circ} \mathrm{C}$ for 2 days for colony-forming unit (CFU) counting. Yeast cells were spotted onto YPD agar containing the DNA damage stress-inducing agents: HU (110 mM), MMS (0.03\%), EMS $(0.04 \%), N$-ethyl-N-nitrosourea (ENU) $(200 \mu \mathrm{g} / \mathrm{mL})$, ethidium bromide solution (EtBr) $(20 \mu \mathrm{g} / \mathrm{mL})$.

For cell viability analyses, yeasts were inoculated in liquid YPD containing MMS $(0.1 \%$ or $0.2 \%)$, EMS $(0.1 \%$ or $0.2 \%)$, methoxy-amine (MX) $(0.417 \mathrm{mg} / \mathrm{mL}$ to $1.67 \mathrm{mg} / \mathrm{mL})$, or Zeocin $(0.4 \%$ to $0.16 \%)$ and incubated for $1 \mathrm{~h}$, at 30 or $37^{\circ} \mathrm{C}$, at $200 \mathrm{rpm}$. Five hundred cells were washed, plated on YPD plates and incubated at $30^{\circ} \mathrm{C}$ for 2 days for CFU counting. The assay was performed as three independent experiments. Statistical test One-way ANOVA with Dunnett's post-test was applied, to compare the results.

For the evaluation of DNA fragmentation, $5 \times 10^{7}$ cells of the $C$. neoformans strains were exposed to $0.08 \%$ Zeocin for $1 \mathrm{~h}$ in YPD liquid medium at $30{ }^{\circ} \mathrm{C}$ at $200 \mathrm{rpm}$. Cells were washed with PBS, and DNA was extracted using the Smash and Grab protocol. One $\mu \mathrm{g}$ of genomic DNA was loaded in $1.5 \%$ agarose gel stained with $0.5 \mu \mathrm{g} / \mathrm{mL}$ EtBr. Genomic DNA from the unexposed H99 strain was used as control. The pattern of DNA migration on agarose gel was compared to genomic DNA of unexposed H99 to define the presence of DNA trail and fragmentation. The assay was performed as three independent experiments.

For the evaluation of the combined action of MX and $\mathrm{H}_{2} \mathrm{O}_{2}, 1 \times 10^{6}$ cells/mL were cultured in YPD medium containing $0.417 \mathrm{mg} / \mathrm{mL}$ MX combined with $3 \mathrm{mM}$ or $5 \mathrm{mM}$ $\mathrm{H}_{2} \mathrm{O}_{2}$, for $1 \mathrm{~h}$, at $30^{\circ} \mathrm{C}$ and $150 \mathrm{rpm}$. Cells grown in YPD containing only $1 \mathrm{mM}$ or $5 \mathrm{mM}$ $\mathrm{H}_{2} \mathrm{O}_{2}$ were used as control. Cell viability was assessed by CFU counting. Results were 
represented in graphs as the ratio of cells exposed to $\mathrm{MX}+\mathrm{H}_{2} \mathrm{O}_{2}$ normalized to the cells exposed to $\mathrm{H}_{2} \mathrm{O}_{2}$. For the survival analysis, cells of the WT and mutant strains were incubated in liquid YPD medium for $1 \mathrm{~h}$, at $30{ }^{\circ} \mathrm{C}$, and $150 \mathrm{rpm}$ in the absence (control) or in the presence of MX $(0,0.417,0.834$ or $1.67 \mathrm{mg} / \mathrm{mL})$. Cells were then PBS-washed and the number of CFUs was assessed. For the analysis of virulence factors after MX exposal, cells from each strain were incubated with $0.417 \mathrm{mg} / \mathrm{mL} \mathrm{MX}$ for $1 \mathrm{~h}$, at $37^{\circ} \mathrm{C}$, PBS-washed, diluted and inoculated for melanin production and urease activity analyses. Visual detection was performed daily and documented after 72, 96 and $144 \mathrm{~h}$ of growth. The assay was performed as three independent experiments.

\subsection{MIC Determination Assays}

A stock solution of each antifungal agent was prepared as recommended by the NCCLS M27-A3 protocol. The following ranges were tested: Amphotericin B (Sigma-Aldrich, St. Louis, MO, USA) 0.125 to $16 \mu \mathrm{g} / \mathrm{mL}$; Fluconazole (Sigma-Aldrich, St. Louis, MO, USA) 0.008 to $64 \mu \mathrm{g} / \mathrm{mL}$. methoxy-amine was tested in the range of 0.125 to $16 \mathrm{mg} / \mathrm{mL}$. One hundred $\mu \mathrm{L}$ of each chemical agent, diluted in RMPI medium, at a two-fold concentration, was placed in duplicate wells of sterile 96-well plates (Corning Glass Works, Corning, NY, USA).

An aliquot of $5 \times 10^{4}$ yeast cells $/ \mathrm{mL}$ in RPMI medium was added to the wells containing the drugs. Plates were then incubated at $37^{\circ} \mathrm{C}$, protected from light. End-points were macroscopically checked after $72 \mathrm{~h}$. MIC (minimum inhibitory concentration) was defined as the lowest concentration at which there was a visually complete inhibition of growth compared to controls. The assay was performed as three independent experiments.

\subsection{Evaluation of Drug Interactions}

The interaction of amphotericin B (AmpB) with methoxy-amine hydrochloride (MX) was evaluated by the microdilution checkerboard method employing the H99, apn1 1 , apn $2 \Delta$ and apn $1 \Delta$ apn $2 \Delta$ strains [45]. The drug concentrations varied from five-fold dilutions below to four-fold above the estimated MIC. Fifty $\mu \mathrm{L}$ of each drug, AmpB and MX, at a two-fold concentration in RPMI medium were added to 96-well plates.

All the strains were grown in YPD broth and incubated for $20 \mathrm{~h}$ at $30^{\circ} \mathrm{C}$ with shaking. Cells were washed with $1 \times$ PBS and the inoculum concentration was adjusted to $1 \times 10^{5}$ cells $\mathrm{mL}^{-1}$. One hundred $\mu \mathrm{L}$ of this solution was added to the wells containing $50 \mu \mathrm{L}$ of both drugs at the $2 \times$ concentration. Positive controls without drugs and negative controls without yeast cells were performed. Plates were protected from light and incubated at $37^{\circ} \mathrm{C}$. After $72 \mathrm{~h}$ of incubation, endpoint cultures were visually read. Tests were performed in two biological replicates.

Cell proliferation was evaluated and fractional inhibitory concentration index (FICI) was calculated as previously described by Pfaller et al., (2015) [45]. FICI was calculated by the equation: $\mathrm{FICI}=(\mathrm{MICa}$ in combination $/ \mathrm{MICa}$ tested alone $)+(\mathrm{MICb}$ in combination/MICb tested alone); MICa: AmpB and MICb: MX. The result of the FICI was interpreted as follows: $\leq 0.5$-synergy, $>0.5$ and $\leq 4.0$-indifferent, $>4.0$-antagonism [45].

\subsection{In Vitro Phagocytosis Assays}

2.9.1. Ethics Statement

All the animal procedures were performed in accordance with national and institutional guidelines for animal care and were approved by the University of Brasilia (UnB) Committee of Ethical Use of Animals (Proc. UnB Doc 52657/2011).

\subsubsection{Infection of Bone Marrow-Derived Macrophages}

Bone marrow-derived macrophages (BMDMs) were obtained as previously described [46], by extracting the bone marrow from femurs and tibiae of C57BL/ 6 mice 8 to 12 weeks old (Animal Facility of the Institute of Biological Sciences of the University of Brasilia). Cells were cultured in vitro on non-treated 100 mm Petri dishes in complete RPMI 1640 medium 
(Thermo Fisher Scientific, Waltham, MA, USA) supplemented with $10 \%$ heat-inactivated fetal bovine serum (Thermo Fisher Scientific, Waltham, MA, USA), $50 \mu \mathrm{g} / \mathrm{mL}$ of gentamicin, $50 \mu \mathrm{M}$ 2-mercaptoethanol (Sigma-Aldrich, St. Louis, MO, USA) and $20 \mathrm{ng} / \mathrm{mL}$ recombinant GM-CSF (PeproTech; Ribeirão Preto, SP, Brazil). The cultures were incubated for 8 days at $37^{\circ} \mathrm{C}$ in a humidified $5 \% \mathrm{CO}_{2}$ atmosphere. On day 3,10 $\mathrm{mL}$ of fresh complete medium was added to the culture. Half of the medium volume was substituted on day 6. On day 8, BMDMs were detached from plates with TrypLE ${ }^{\mathrm{TM}}$ Express (Thermo Fisher Scientific, Waltham, MA, USA) and collected.

\subsubsection{Phagocytosis Assay}

Approximately $5 \times 10^{4}$ BMDMs were plated onto each well of 96-well polystyrene microplates with $100 \mu \mathrm{L}$ of RPMI medium supplemented with 10\% FBS. The cultures were incubated for $24 \mathrm{~h}$ at $37{ }^{\circ} \mathrm{C}$ in a humidified $5 \% \mathrm{CO}_{2}$ atmosphere. The supernatant was removed and $2.5 \times 10^{5}$ yeast cells of $C$. neoformans (Multiplicity of Infection; $\mathrm{MOI}=5$ ) were added to each well in $100 \mu \mathrm{L}$ of RPMI medium supplemented with $10 \%$ FBS and the $18 \mathrm{~B} 7$ $\mathrm{mAb}$ (kindly donated by Dr. Arturo Casadevall, Johns Hopkins University, Baltimore, MD, USA) at $10 \mu \mathrm{g} / \mathrm{mL}$. The co-cultures of $C$. neoformans strains with macrophages were then incubated for 2 or $24 \mathrm{~h}$ post-infection (hpi) at $37^{\circ} \mathrm{C}$ in a humidified $5 \% \mathrm{CO}_{2}$ atmosphere. After $2 \mathrm{~h}$ of interaction, non-internalized yeast cells were removed by rinsing the wells with PBS. For the $24 \mathrm{~h}$ assays, fresh pre-warmed RPMI medium with $10 \%$ FBS was added to the wells.

For the quantitation of phagocytosis, cells were fixed and stained with Fast Panoptic kit (Laborclin, Pinhais, PR, Brazil). Under the Axio Observer Primovert GmbH microscope (Carl Zeiss Microscopy, Jena, Germany), 200 macrophages per well were observed for the determination of the percentage of phagocytosis (percentage of macrophages that have phagocytized one or more yeasts relative to the total number of cells counted) and the phagocytic index (the average number of phagocytized yeast cells per BMDM).

To determine the ability of the C. neoformans strains to proliferate inside BMDMs, colony-forming unit (CFU) assays were performed after 2 or $24 \mathrm{~h}$ of co-culture. After the incubation periods, yeast cells were released by lysing the macrophages with $0.05 \%$ SDS (Sodium dodecyl sulfate). For the $24 \mathrm{~h}$ assay, the supernatant and lysate were pooled. The number of CFUs was determined by serial dilution of each sample plated on YPD agar incubated at $30{ }^{\circ} \mathrm{C}$ and counted after $48 \mathrm{~h}$. The phagocytic activity, defined as the number of CFUs obtained from a well at the two-hour time point, and intracellular growth, defined as the number of CFUs from the $24 \mathrm{~h}$ time point, were determined.

Three independent experiments were performed in technical triplicate. The multiple group comparisons were conducted by one-way analysis of variance (ANOVA) followed by Dunnett's post-test. For the comparison of proportions, the Chi-square test was performed with a $p$-value $<0.05$.

\subsection{Wax Moth Larvae Infection}

G. mellonella infection was performed as previously described by Garciá-Rodas et al. [47]. Briefly, 16 randomly collected G. mellonella larvae were inoculated with $10 \mu \mathrm{L}$ of a $10^{6}$ yeast cells/mL suspension by injection in the last left pro-leg using a sterile 26-gauge needle-fitted Hamilton syringe. G. mellonella larvae were inoculated with $1 \times$ PBS as control for the physical injury. Larval survival was daily evaluated for 7 days. Larval death was defined by the absence of movement in response to touch.

\subsection{Statistical Analyses}

Data are presented as the mean \pm standard deviation (SD) unless otherwise stated. The statistical analysis was performed using software GraphPad Prism version 6.0 for Windows (GraphPad Software, San Diego, CA, USA, www.graphpad.com, accessed on 11 February 2021). The appropriate test is indicated for each experiment. $p$ values $\leq 0.05$ were considered statistically significant. 


\section{Results}

\subsection{Apn2-Like C. neoformans Is an ExoIII/Ape1 Member of the AP Endonucleases Family}

The nucleotide sequences of S. cerevisiae ScApn1 (NCBI ID 853746) and ScApn2 (NCBI ID 852262) were used as queries for the NCBI BLASTp search against six-frame translations of the C. neoformans sequence database. The sequences CNAG_05468 and CNAG_04268 of the C. neoformans genome presented the highest identity with ScApn1 and ScApn2 sequences, respectively. C. neoformans Apn1 (CnApn1) predicted protein contains 483 amino acid residues, compared to 719 aa of the putative CnApn2 protein. Both deducted sequences share only $22.51 \%$ identity. The predicted CnApn1 protein presents two discrete domains: a xylose isomerase-like domain (position 138), and an nfo-apurinic endonuclease domain (endonuclease IV-like protein; position 428). The CnApn1 putative protein presents $48.3 \%$ identity with the Apn1 of S. pombe, $45.8 \%$ with the E. coli Endonuclease IV, $43.9 \%$ with the Apn1 of C. albicans and $42.4 \%$ identity with the S. cerevisiae Apn1 (Figure 1A).

$\mathbf{A}$

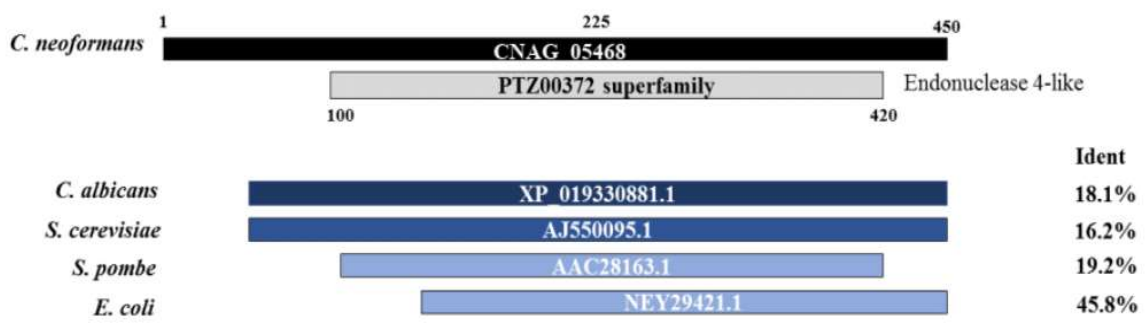

B

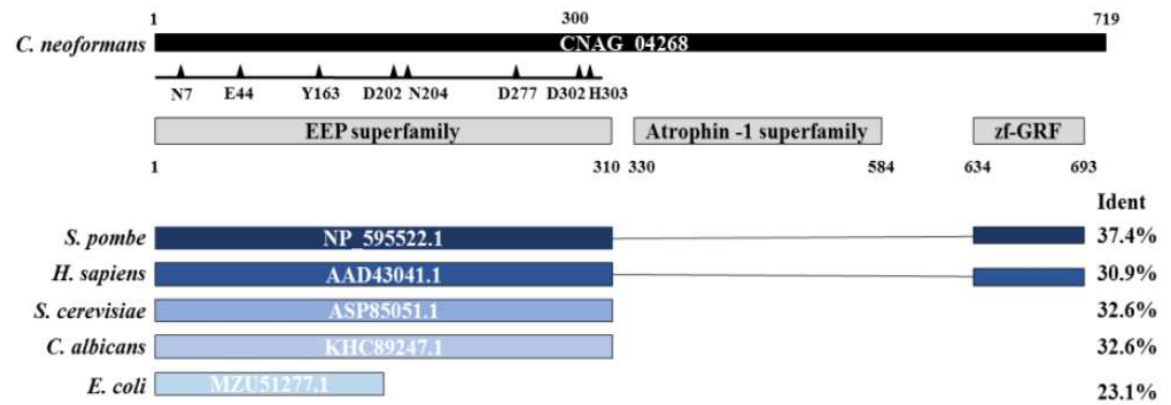

Figure 1. Comparative analysis of Apn deduced amino acid sequences. APN1-like (CNAG_05468) and APN2-like (CNAG_04268) gene sequences from C. neoformans were used as query for Blastp analyses. (A) Alignment results of Apn1 amino acid sequences from C. albicans, S. pombe, S. cerevisiae and E. coli, highlighting the cover and identity with the C. neoformans Apn1-like amino acid sequence. (B) Alignment results of Apn2 sequences from S. pombe, H. sapiens, C. albicans, S. cerevisiae and E. coli, highlighting the cover and identity with the $C$. neoformans Apn2-like deduced amino acid sequences. NCBI accession numbers are depicted in each protein representation. Triangles represent key-amino acids for the catalytic sites; Ident: percentage of amino acid identity provided by Blastp analysis on NCBI. EEP: exonuclease-endonuclease-phosphatase. zf-GRF: zinc finger domain.

The sequence CNAG_04268, encoding a putative exodes-oxyribonuclease III, was defined as the putative Apn2 of C. neoformans, and used as a query for BLASTp analyses on NCBI against the genomes of S. pombe, Homo sapiens, S. cerevisiae, C. albicans, and E. coli (Figure 1B). The predicted C. neoformans Apn2 shares several conserved and essential amino acid residues with S. pombe Apn2, human APE2 and S. cerevisiae Apn2.

The N-terminal region of the Apn2-like protein contains an Exonuclease-EndonucleasePhosphatase (EEP) superfamily domain, conserved in all the analyzed species. This large superfamily includes the catalytic domain of a diverse set of proteins, including the ExoIII family of AP endonucleases [48]. In contrast to the Apn2 proteins from other organisms, the putative C. neoformans Apn2 presents an Atrophin-1 domain. Atrophin proteins are 
conserved transcriptional corepressors involved in nuclear receptor signaling [49]. About 250 amino acid residues, corresponding to the atrophin-1 superfamily domain of Apn2, are missing in the Apn1-like protein (Figure 1A).

\section{2. apn1 $1 \Delta$, apn $2 \Delta$ and apn $1 \Delta a p n 2 \Delta$ Mutant Strains Do Not Differ from the Parental Strain} Regarding Osmotic or Oxidative Stress Sensitivity

AP-endonucleases knockout mutants were generated by homologous recombination after biolistic transformation of the $\mathrm{H} 99$ strain. To confirm the precise replacement of the $A P N 1$ and APN2 loci with the selective marker, multiple combinations of PCR primers were used (Figure S1A,B). The double mutant apn1 $\triangle a p n 2 \Delta$ strain was also obtained. In order to verify if eventual phenotype alterations were indeed due to the deletion of the DNA sequences, $A P N 1$ and $A P N 2$ putative genes were reintroduced into the mutant strain's genome, to create the reconstituted strains. The reintroduction of the sequences into the mutant strains genomes was confirmed by PCR (Figure S1A,B).

Initially, we evaluated if the putative $A P N 1$ and $A P N 2$ genes affected growth or viability of $C$. neoformans yeast cells. We observed no effect of the single or the double deletions on the growth in solid YPD or on their growth kinetics in liquid YPD broth at 30 or at $37^{\circ} \mathrm{C}$ in comparison to the WT strain (Figures S2 and S3). To evaluate the potential role of $A P N$-like genes for $C$. neoformans survival under stress conditions, apn1 $\triangle$, apn $2 \Delta$ and the apn $1 \triangle a p n 2 \Delta$ double mutant strains were tested for stress-related phenotypes. Overall, disruption of $A P N 1, A P N 2$ or of both genes simultaneously induced mild defective phenotypes in response to cell surface stressors (sodium dodecyl sulfate, Sorbitol, caffeine), but none of the genotoxic (Cadmium sulfate $\left(\mathrm{CaSO}_{4}\right)$ or osmotic (sodium chloride $(\mathrm{NaCl})$ potassium chloride $(\mathrm{KCl})$ ) stressors, at the tested concentrations, affected the growth of the C. neoformans mutant strains at 30 or $37^{\circ} \mathrm{C}$ (Figure S2A,B). Additionally, we did not observe any significant difference in the mutant's response to oxidative stress induced by menadione (MND), sodium nitrite $\left(\mathrm{NaNO}_{2}\right)$ or hydrogen peroxide $\left(\mathrm{H}_{2} \mathrm{O}_{2}\right)$ (Figure $\mathrm{S4}$ ). These data demonstrate that the putative APN1 and APN2 sequences are not essential for growth or response of $C$. neoformans to those stressors.

\subsection{C. neoformans APN1 and APN2-Like Genes Are Involved in the Repair of DNA Radiation-Induced Lesions}

To assess if the CnApn1 and CnApn2 predicted proteins participate in the repair of radiation-derived DNA lesions, WT and mutant strains were exposed to different UV radiation dosages, and the viability of fungal cells was evaluated. Disruption of APN1 and $A P N 2$-like sequences resulted in increased susceptibility of $C$. neoformans to UV radiation (Figure 2). Deletion of both the $A P N$-like genes induced a higher sensitivity to UV radiation when compared to the single mutant strains' phenotypes (Figure 2A). The susceptibility of the strains to UV radiation was also investigated by plating on YPD agar a defined number of cells after irradiation with 120, 240 and $480 \mathrm{~J} / \mathrm{m}^{2}$ at $254 \mathrm{~nm}$. Yeasts' viability was estimated by CFU counting, and the results indicated that the disruption of APN2 significantly affected the $C$. neoformans survival in a radiation dose-dependent manner (Figure 2B). Even though moderate resistance to UV radiation was observed for the apn1 $\triangle$ strain when compared to the WT, the double deletion of APN1 and APN2 promoted an even higher sensitivity to UV radiation than the APN2 single mutation (Figure 2B). 
A

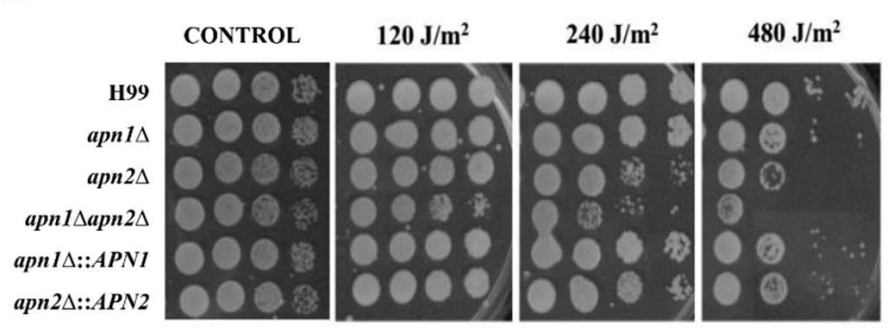

B

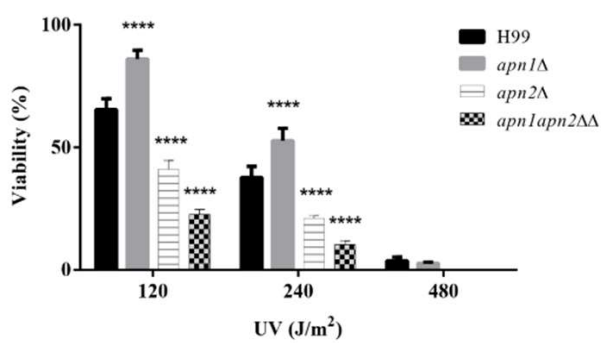

Figure 2. Disruption of Apn1- and Apn2-like genes induced C. neoformans susceptibility to UV radiation. (A) Ten-fold serial dilutions of $C$. neoformans WT, mutant and reconstituted strains of yeasts were exposed to 120,240 and $480 \mathrm{~J} / \mathrm{m}^{2} \mathrm{doses}$ of UV radiation $\left(254 \mathrm{~nm}\right.$ ) and grown at $30{ }^{\circ} \mathrm{C}$, for $48 \mathrm{~h}$. The results are representative of at least three independent experiments. (B) Cell viability (\%) after UV irradiation. C. neoformans $5 \times 10^{2}$ cells were plated on YPD agar and exposed to UV radiation at 120,240 and $480 \mathrm{~J} / \mathrm{m}^{2}$ at $254 \mathrm{~nm}$. The plates were incubated at $30^{\circ} \mathrm{C}$ for $48 \mathrm{~h}$, protected from light, for colony forming unit (CFU) counting. Graph represents the percentage of viable cells normalized by the percentage of viable control cells. The WT H99 strain was used as control for statistical comparison. One-way analysis of variance (ANOVA) with Dunnett's post-test was used to compare the means of results from three independent experiments. Error bars represent standard errors of the mean. ${ }^{* * * *} p<0.0001$.

3.4. The Putative Apn2 Endonuclease Is Involved in Processing Alkylation-Induced DNA Damage in C. neoformans

In order to evaluate the possible roles of CnApn1 and CnApn2 predicted proteins in the repair of different types of DNA lesions, the growth of the mutant strains was evaluated after their exposure to different mutagenic agents. Neither the single mutant $(a p n 1 \Delta$ and $a p n 2 \Delta)$ nor the double mutant $(a p n 1 \Delta a p n 2 \Delta)$ strains displayed any growth difference in comparison to the WT strain after exposure to hydroxyurea (HU, $110 \mathrm{mM})$, the alkylating compounds methyl methane-sulfonate (MMS, $0.03 \%$ ), ethyl methane-sulfonate (EMS, $0.04 \%$ ) and N-ethyl-N-nitrosourea (ENU, $200 \mu \mathrm{g} / \mathrm{mL}$ ), or the intercalating agent ethidium bromide (EtBr, $20 \mu \mathrm{g} / \mathrm{mL}$ ) (Figure 3A).

We further submitted the mutants to higher concentrations of MMS and/or EMS $(0.1 \%$ or $0.2 \%$ ) for $1 \mathrm{~h}$, at $30^{\circ} \mathrm{C}$, followed by CFU counting to access yeasts' viability (Figure 3B). Cells from the apn $1 \Delta$ single mutant were only sensitive to MMS-induced stress at both tested concentrations. At $0.2 \%$ MMS, the survival of $C$. neoformans apn $2 \Delta$ was drastically reduced to less than $10 \%$ in comparison to the wild-type cells (75\% survival). Treatment with EMS also promoted, to a lesser extent than MMS, a reduced viability of the apn $2 \Delta$ mutant in relation to the WT strain. In comparison to the wild-type and single-gene deletion strains, the apn $1 \Delta a p n 2 \Delta$ double mutant was more sensitive to higher concentrations of MMS and EMS. These results indicate a major involvement of CnApn2 in the response to MMS and EMS-induced alkylated DNA.

\subsection{The Deletion of APN-Like Genes Results in Increased Sensitivity to Zeocin and DNA Fragmentation}

Zeocin is a genotoxic drug that intercalates into the DNA, provoking double-strand breaks [50]. To evaluate the influence of the predicted Apn proteins in the response of C. neoformans to Zeocin, the mutant and WT strains were exposed to different concentrations of the drug, for $1 \mathrm{~h}$. The deletion of APN1 and APN2 resulted in increased sensitivity to Zeocin even in low doses $(0.04 \%$ or $0.08 \%$ ) (Figure $4 \mathrm{~A})$. 
A

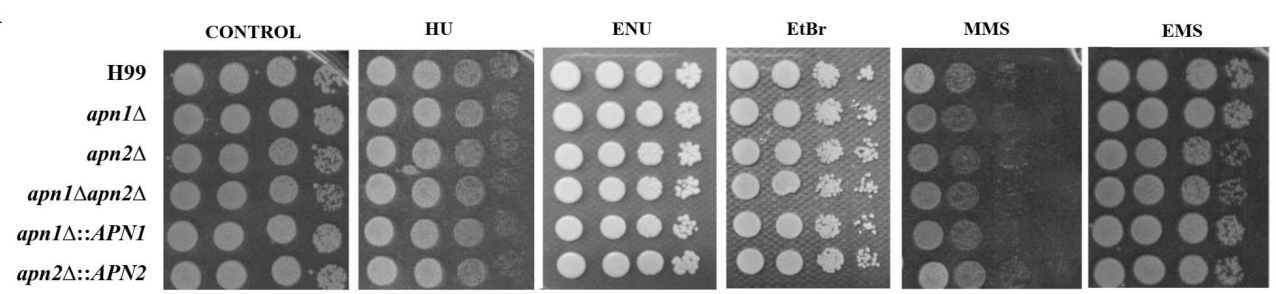

B

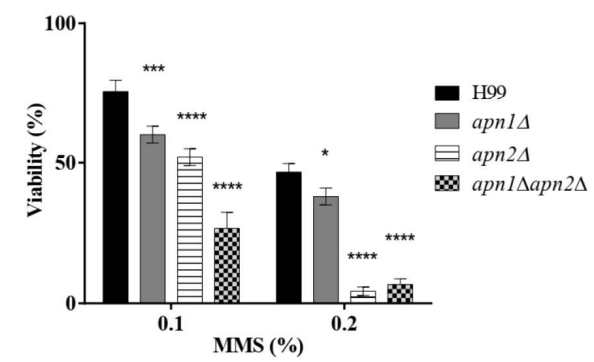

C

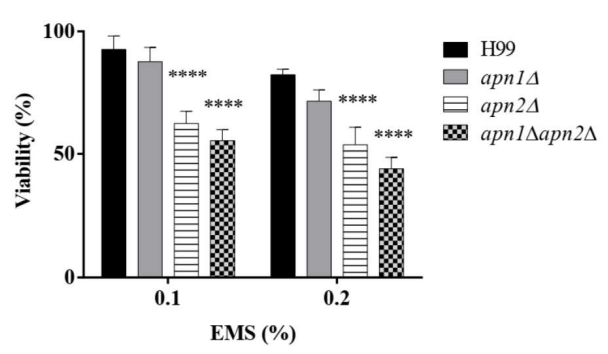

Figure 3. Predicted Apn2 endonuclease is required for yeast viability after exposure to DNA-alkylating agents. (A) The different strains were serially diluted ten-fold and plated onto YPD agar supplemented with DNA damage-inducing agents: $0.03 \%$ methyl methane-sulfonate (MMS), $0.04 \%$ ethyl methane-sulfonate (EMS), $200 \mu \mathrm{g} / \mathrm{mL}$ N-ethyl-N-nitrosourea (ENU), $20 \mu \mathrm{g} / \mathrm{mL}$ ethidium bromide (EtBr) or $110 \mathrm{mM}$ hydroxyurea (HU). The plates were incubated at $30{ }^{\circ} \mathrm{C}$ for $48 \mathrm{~h}$. The results are representative of three independent experiments. (B) Cell viability after exposure to 0.1 or $0.2 \%$ MMS or (C) 0.1 or $0.2 \%$ EMS. The strains were exposed to the agents in liquid YPD for $1 \mathrm{~h}$, at $30^{\circ} \mathrm{C}$ and $150 \mathrm{rpm}$. Cells were then phosphate-buffer saline- (PBS)-washed and plated on YPD agar for CFU counting. The graphs represent the percentage of viable cells normalized by the percentage of viable control cells. The WT H99 strain was used as control for statistical comparison. One-way ANOVA with Dunnett's multiple-comparisons test was used to compare the means of results from three independent experiments. Error bars represent standard errors of the mean. ${ }^{* * * *} p<0.0001$; ${ }^{* * *} p<0.001 ;{ }^{*} p<0.05$.

A

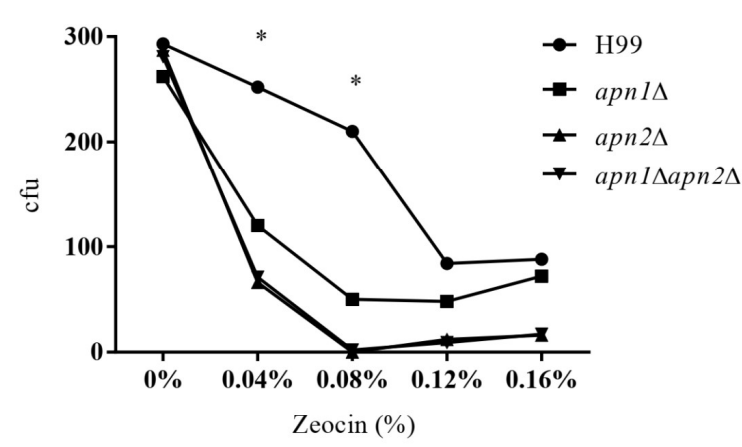

B

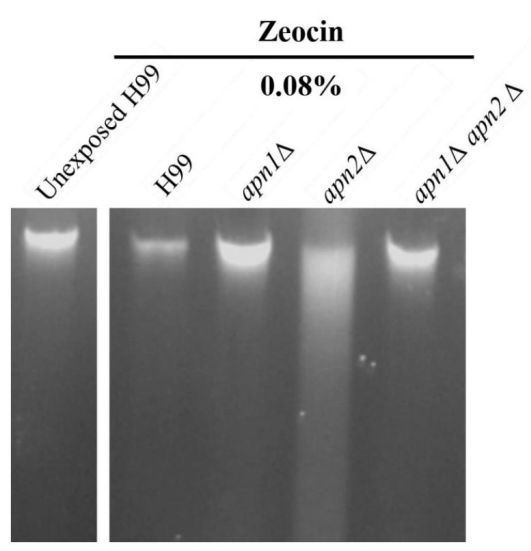

Figure 4. The ablation of the predicted Apn1 and Apn2 proteins sensitized C. neoformans yeasts to the exposure to Zeocin. (A) Cell viability of the WT and mutant strains after incubation with different concentrations of Zeocin. Yeasts from WT and mutant strains were cultured in liquid YPD containing $0.04 \%, 0.08 \%, 0.12 \%$ or $0.16 \%$ Zeocin for $1 \mathrm{~h}$, at $30^{\circ} \mathrm{C}, 150 \mathrm{rpm}$. Cells were then PBS-washed and plated on YPD agar for CFU counting. Percent of viable cells was calculated from the CFU counting. Data are presented as mean of three replicates. Statistical test: One-way ANOVA with Dunnett's post-test, ${ }^{*} p<0.05$. (B) Electrophoretic analysis in $1 \%$ agarose gel stained with $0.5 \mu \mathrm{g} / \mathrm{mL}$ EtBr of $C$. neoformans strains DNA after exposure to $0.08 \%$ Zeocin for $1 \mathrm{~h}$. Unexposed mutant and $\mathrm{H} 99$ strains presented DNA with no fragmentation. Genomic DNA from the unexposed $\mathrm{H} 99$ strain was used as control. The result is representative of three independent experiments.

To investigate the possible contribution of the putative AP-endonucleases in the protection of $C$. neoformans DNA from the damage provoked by Zeocin, we qualitatively 
analyzed the DNA fragmentation in the WT, apn1 1 , apn $2 \Delta$ and apn $1 \Delta a p n 2 \Delta$ mutant strains. Unexposed and $(0 \mathrm{~h})$ control cells showed almost undetectable levels of DNA fragmentation (Figure 4B). Nonetheless, DNA smearing was observed after $1 \mathrm{~h}$ of exposure to $0.08 \%$ Zeocin for all the strains (Figure 4B). The apn $2 \Delta$ mutant displayed a marked increase in Zeocininduced DNA fragmentation in comparison to the WT (Figure 4B). The increase in DNA fragmentation in apn $2 \Delta$ suggests a reduced DNA repair capability.

3.6. The Inhibition of Recognition of Abasic Sites by Methoxy-Amine Enhances the Fungicidal Effect of Amphotericin B

Amphotericin $\mathrm{B}(\mathrm{AmpB})$ generation of reactive oxygen species contributes to the fungicidal effect of this drug [49]. We then decided to evaluate whether compounds that inhibit the corrections of oxidative lesions, such as the anti-cancer chemotherapeutic drug methoxy-amine (MX), could increase the antifungal effect of AmpB. We first determined the MIC values for MX, AmpB and Fluconazole alone for each strain (Table 1). The mutant strains apn $2 \Delta$ and apn1 $\Delta a p n 2 \Delta$ presented MIC values of $1.0 \mu \mathrm{g} / \mathrm{mL}$ of Fluconazole, half of the MIC values presented by the $\mathrm{H} 99$, apn $1 \Delta$ and reconstituted strains $(2.0 \mu \mathrm{g} / \mathrm{mL})$. Based on these values, we used different combinations of the $\mathrm{MX}$ and $\mathrm{AmpB}$ drugs for a checkerboard assay, to evaluate a possible drug interaction. The combination of AmpB and MX showed synergism against all the strains. The combination of these drugs was more effective against the $a p n 2 \Delta(\mathrm{FICI}=0.187)$ and $a p n 1 \Delta a p n 2 \Delta(\mathrm{FICI}=0.219)$ strains than for H99 (FICI = 0.375) and apn1 $($ FICI = 0.312) $($ Table 2).

Table 1. MIC values of amphotericin B (AmpB), methoxy-amine hydrochloride (MX) and Fluconazole

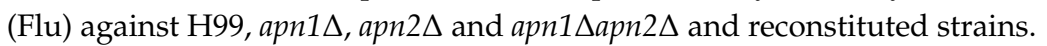

\begin{tabular}{|c|c|c|c|c|c|c|}
\hline \multirow[b]{2}{*}{ Strains } & \multicolumn{3}{|c|}{ Replicate 1} & \multicolumn{3}{|c|}{ Replicate 2} \\
\hline & $\begin{array}{c}\text { AmpB } \\
(\mu \mathrm{g} / \mathrm{mL})\end{array}$ & $\begin{array}{c}\text { MX } \\
(\mathrm{mg} / \mathrm{mL})\end{array}$ & $\begin{array}{c}\text { Flu } \\
(\mu \mathrm{g} / \mathrm{mL})\end{array}$ & $\begin{array}{c}\text { AmpB } \\
(\mu \mathrm{g} / \mathrm{mL})\end{array}$ & $\begin{array}{c}\text { MX } \\
(\mathrm{mg} / \mathrm{mL})\end{array}$ & $\begin{array}{c}\text { Flu } \\
(\mu \mathrm{g} / \mathrm{mL})\end{array}$ \\
\hline H99 & 0.25 & 1.25 & 2 & 0.25 & 1.25 & 2 \\
\hline apn1 $1 \Delta$ & 0.25 & 1.25 & 2 & 0.25 & 1.25 & 2 \\
\hline $\operatorname{apn} 2 \Delta$ & 0.125 & 0.626 & 1 & 0.125 & 0.626 & 1 \\
\hline apn1 1 apn $2 \Delta$ & 0.125 & 0.626 & 1 & 0.125 & 0.626 & 1 \\
\hline apn1 $1 \triangle:: A P N 1$ & 0.25 & 1.25 & 2 & 0.25 & 1.25 & 2 \\
\hline apn2 $2:: A P N 2$ & 0.25 & 1.25 & 2 & 0.25 & 1.25 & 2 \\
\hline
\end{tabular}

Table 2. MIC values of amphotericin B (AmpB) and methoxy-amine hydrochloride (MX) in combinations and fractional inhibitory concentration index (FICI) values.

\begin{tabular}{|c|c|c|c|c|c|c|}
\hline \multirow{2}{*}{ Strains } & \multicolumn{3}{|c|}{ Replicate 1} & \multicolumn{3}{|c|}{ Replicate 2} \\
\hline & MICab & MICba & FICI & MICab & MICba & FICI \\
\hline H99 & 0.0625 & 0.292 & 0.50 & 0.0312 & 0.150 & 0.2498 \\
\hline apn1s & 0.0156 & 0.292 & 0.3124 & 0.0625 & 0.078 & 0.3125 \\
\hline $\operatorname{apn} 2 \Delta$ & 0.0078 & 0.078 & 0.1874 & 0.0078 & 0.078 & 0.1874 \\
\hline apn1 1 apn $2 \Delta$ & 0.0156 & 0.078 & 0.2498 & 0.0078 & 0.078 & 0.1874 \\
\hline
\end{tabular}

MICab: MIC of AmpB in combination with MX. MICba: MIC of MX in combination with AmpB. The AmpB concentrations are expressed in $\mu \mathrm{g} / \mathrm{mL}$, and for $\mathrm{MX}$ in $\mathrm{mg} / \mathrm{mL}$.

Since MX inhibits the recognition and correction of abasic sites by AP-endonucleases, we investigated the effect of $\mathrm{MX}$ exposure in combination with $\mathrm{H}_{2} \mathrm{O}_{2}$-induced oxidative stress in WT and APN-like genes' mutant strains (Figure 5). The strains were exposed to $3 \mathrm{mM}$ or $5 \mathrm{mM} \mathrm{H}_{2} \mathrm{O}_{2}$ in combination with $0.417 \mathrm{mg} / \mathrm{mL} \mathrm{MX}$, for $1 \mathrm{~h}$, at $30^{\circ} \mathrm{C}$ and $150 \mathrm{rpm}$. Yeasts' viability was assessed by CFU counting. The exposure to $3 \mathrm{mM} \mathrm{H}_{2} \mathrm{O}_{2}$ combined with $\mathrm{MX}$ provoked a significant decrease in cell viability for the apn $1 \Delta$ and the apn $1 \Delta a p n 2 \Delta$ 
mutant strains (Figure 5B), but not apn $2 \Delta$. After exposure to $5 \mathrm{mM} \mathrm{H}_{2} \mathrm{O}_{2}$ and $\mathrm{MX}$, there was a marked reduction of CFU recovery for all the strains.

A

$3 \mathrm{mM} \mathrm{H}_{2} \mathrm{O}_{2}$

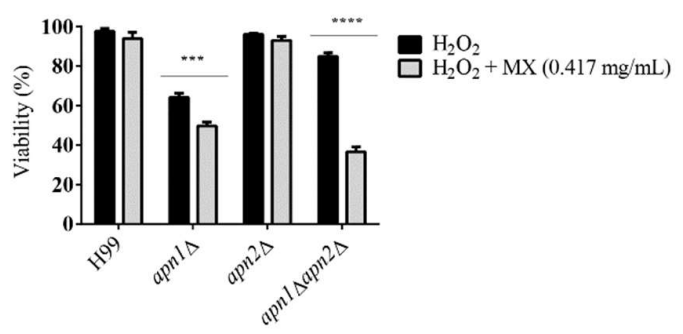

B $5 \mathrm{mM} \mathrm{H}_{2} \mathrm{O}_{2}$

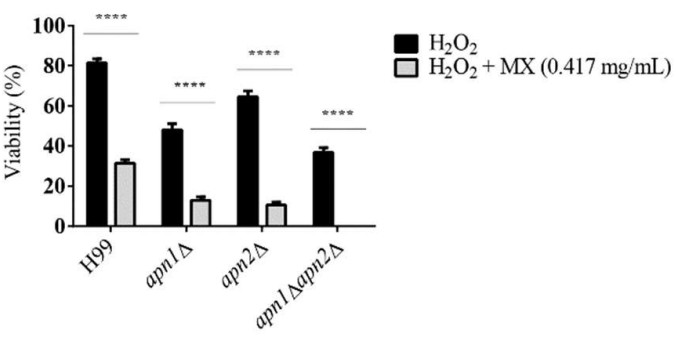

Figure 5. Methoxy-amine (MX) enhances the effects of $\mathrm{H}_{2} \mathrm{O}_{2}$ on the viability of the C. neoformans apn $1 \Delta$ apn $2 \Delta$ mutant strain yeasts. Cell survival of $C$. neoformans WT and mutant strains for the combined exposure to MX and $\mathrm{H}_{2} \mathrm{O}_{2} \mathrm{Strains}_{\text {were }}$ cultured in liquid YPD containing $0.417 \mathrm{mg} / \mathrm{mL} \mathrm{MX}$ and (A) 3 or (B) $5 \mathrm{mM} \mathrm{H}_{2} \mathrm{O}_{2}$, for $1 \mathrm{~h}$, at $30{ }^{\circ} \mathrm{C}$ and $150 \mathrm{rpm}$. Cells incubated only in YPD containing 3 or $5 \mathrm{mM} \mathrm{H}_{2} \mathrm{O}_{2}$ were used as comparison. The graph represents the percent of survival of each strain exposed to each condition described compared to the control condition (YPD medium). Two-way ANOVA with Sidak's multiple-comparisons test was used to compare the means of results from three independent experiments. Error bars represent standard errors of the mean. ${ }^{* * * *} p<0.0001$; $^{* * *} p<0.001$.

\subsection{The CnApn1 and CnApn2-Like Sequences Are Required for the Production of Melanin}

We also evaluated the involvement of the predicted BER proteins CnApn1 and CnApn2 in the expression of some virulence-associated phenotypes of C. neoformans in vitro, such as the polysaccharide capsule, phospholipase and urease activities and melanization. We did not observe any defect in the capsule expansion after growth on inducing conditions at 30 or $37^{\circ} \mathrm{C}$ (Figure S5A), phospholipase (Figure S5B) or urease activity (Figure S5C) in the mutant strains. However, deletion of $A P N 2$, but not of $A P N 1$, induced a marked delay in melanin production by $\mathrm{C}$. neoformans at $37^{\circ} \mathrm{C}$ in $1 \mathrm{mM}$ L-DOPA-inducing medium (Figure 6). Prolonged incubation ( $144 \mathrm{~h}$ ) resulted in late melanization of the apn $2 \Delta$ and apn1 1 apn $2 \Delta$ strains. This defect did not seem to be related to impaired cell growth or density, because there were no significant differences in CFU counts at 72 or $144 \mathrm{~h}$ after melanin synthesis among the strains (data not shown). The delayed melanin synthesis was reversed in the apn $2 \triangle:: A P N 2$ reconstituted strain (Figure 6).

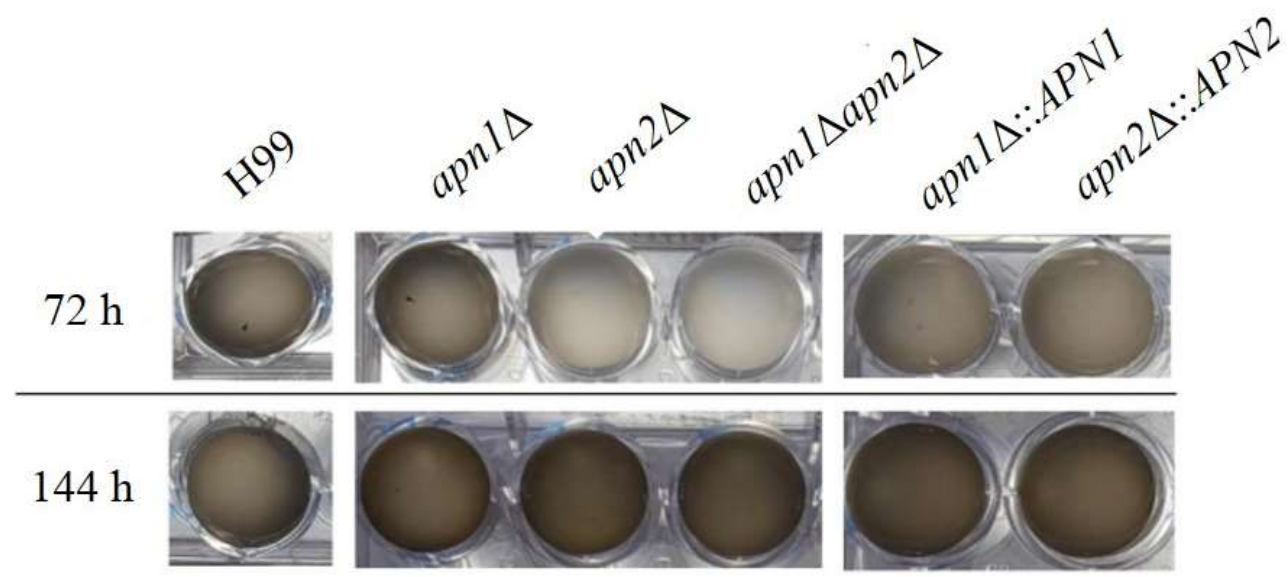

Figure 6. The disruption of the Apn2-like gene of C. neoformans impairs melanin production. C. neoformans yeasts were incubated in melanin-inducing minimal medium with $1 \mathrm{mM} \mathrm{L}$-DOPA at $37^{\circ} \mathrm{C}, 150 \mathrm{rpm}$, protected from light. Melanin production was visually assessed by the medium color change from translucent to brown and photo-documented at 72 and $144 \mathrm{~h}$. The result is representative of three independent experiments. 


\subsection{The Recognition and Correction of Abasic Sites in DNA Is Required for Proper Melanin Production by C. Neoformans}

To confirm the role of C. neoformans Apn2 in melanin production, we decided to investigate the effects of MX presence during the induction of melanin synthesis. First, we evaluated possible effects on MX on fungal viability by treating cells of the different strains with $0.417,0.834$ or $1.67 \mathrm{mM}$ of this compound for $1 \mathrm{~h}$ at $30^{\circ} \mathrm{C}$. As, at $0.417 \mathrm{mg} / \mathrm{mL}$, this drug was not lethal to either the WT or mutant strains (Figure 7A), this concentration was chosen for the next experiments. The different strains were exposed to $0.417 \mathrm{mg} / \mathrm{mL}$ MX, washed and subject to melanin-inducing conditions. The pre-treatment of C. neoformans with MX delayed and reduced the melanization levels of the wild-type strain (Figure 7B), resulting in a phenotype similar to the one observed for the unexposed apn $2 \Delta$ and apn $1 \Delta a p n 2 \Delta$ mutant strains under inducing conditions at $37^{\circ} \mathrm{C}$ (Figure $7 \mathrm{~B}$ ). These effects were not associated with cell death, because there was no differences in CFU counts between untreated and treated samples (Figure 7C). Even after 10 days of incubation, the melanization levels of MX-treated wild-type or mutant strains did not increase (data not shown).

A

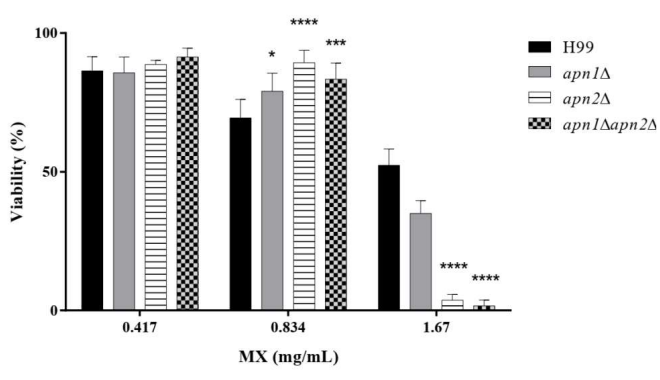

C

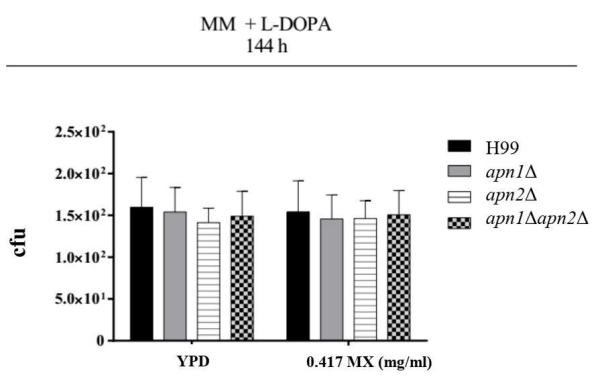

B

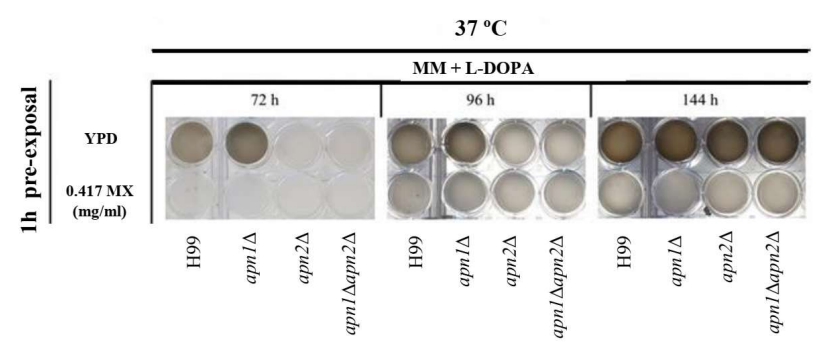

Figure 7. Apn1- and Apn2-like genes are required for melanin production by C. neoformans. (A) Viability of C. neoformans cells after exposure to methoxy-amine (MX). Cells of the WT and mutant strains were incubated in liquid YPD medium for $1 \mathrm{~h}$, at $30^{\circ} \mathrm{C}$, and $150 \mathrm{rpm}$ in the absence (control) or in the presence of $\mathrm{MX}(0,0.417,0.83$ or $1.67 \mathrm{mg} / \mathrm{mL})$. Cells were then PBS-washed and the number of CFUs was assessed. The graph represents the percent of survival of each strain exposed to MX compared to the control condition. The wild-type H99 was used as a control group for statistical comparison. One-way ANOVA with Dunnett post-test was used to compare the means of results from three independent experiments. Error bars represent standard errors of the mean. ${ }^{* * *} p<0.0001 ;{ }^{* *} p<0.001 ;{ }^{*} p<0.05$. (B) Melanin production after exposure of yeast cells to MX. Cells from each strain were incubated with $0.417 \mathrm{mg} / \mathrm{mL} \mathrm{MX}$ for $1 \mathrm{~h}$, at $37^{\circ} \mathrm{C}$, PBS-washed, diluted and inoculated for melanin production analyses. Visual detection was performed daily and photo-documented after 72,96 and $144 \mathrm{~h}$ of growth. Results are representative of three independent experiments. (C) Cell viability of C. neoformans strains after MX exposure and induction of melanin synthesis. Aliquots of cell suspensions were collected from the melanin assay plates after $144 \mathrm{~h}$ of incubation, and viable colonies were assessed by CFU counting. One-way ANOVA with Dunnett's post-test was used to compare the means of results from three independent experiments.

\subsection{Predicted C. neoformans Apn1 and Apn2 Proteins Influence Phagocytosis and Fungal Survival within Macrophages In Vitro}

Phagocytes play multiple roles in cryptococcal pathogenesis, and the ability to survive and proliferate inside phagocytes is associated with patient outcome [51]. To access the 
impact of Apn1 and Apn2 on C. neoformans virulence, we evaluated the in vitro interaction of the mutant strains with macrophages (activated BMDMs) by means of phagocytosis and killing assays. We observed a decrease in the rates of internalization and in the total number of internalized yeast cells from mutant strains in comparison to the WT (Figure 8A,B). In addition, the deletion of the APN2-like gene led to a reduced number of viable C. neoformans cells recovered from the macrophages (Figure $8 \mathrm{C}, \mathrm{D}$ ). Similar results were obtained for the apn $1 \triangle a p n 2 \triangle$ double mutant. In contrast, the absence of the APN1-like gene did not change the number of fungal CFUs after the interaction.

A

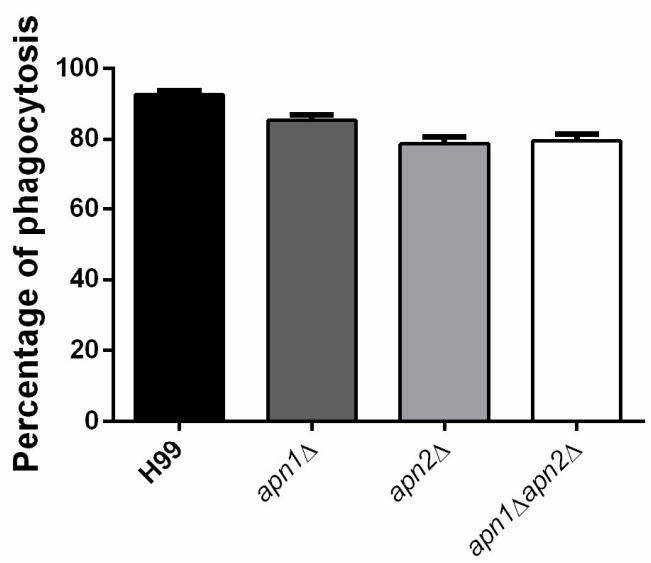

C

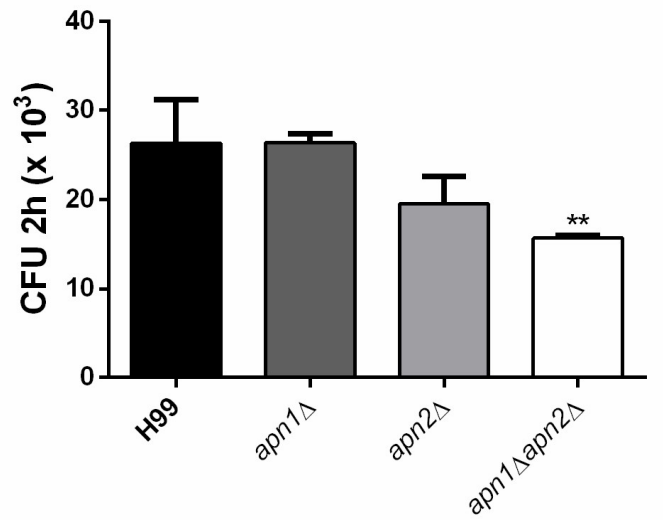

B

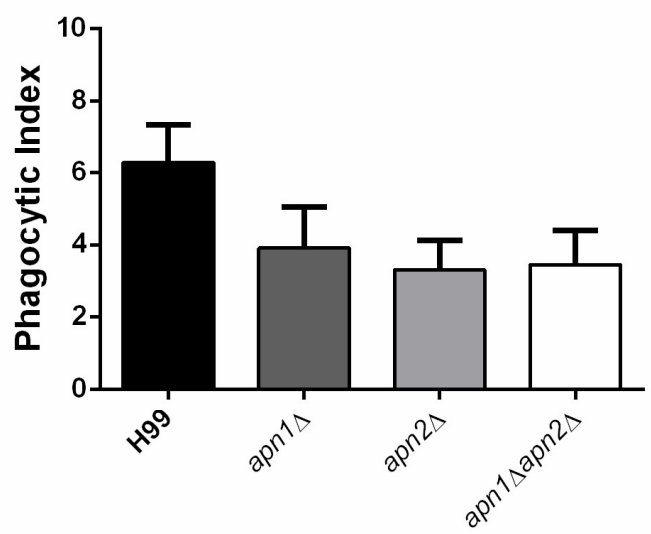

D

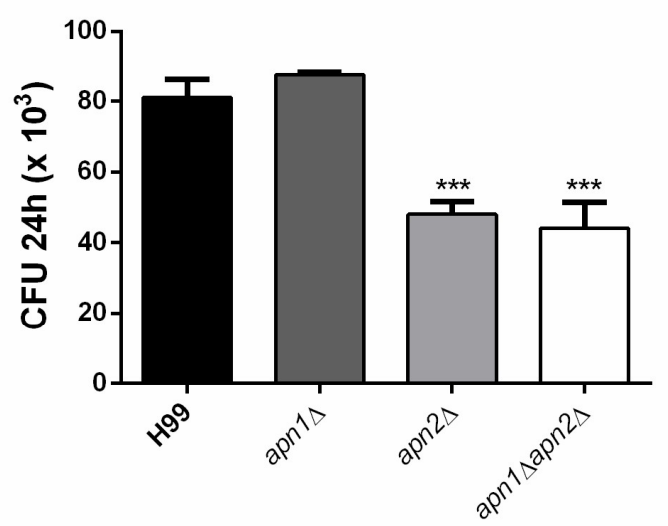

Figure 8. The deletion of APN-like genes results in C. neoformans reduced phagocytosis and survival in macrophages in vitro. Bone marrow-derived macrophages (BMDMs) were co-cultured for $2 \mathrm{~h}$ or $24 \mathrm{~h}$ with previously opsonized fungal cells from the different strains of $C$. neoformans. Each strain was inoculated into three wells of a 96-well polystyrene plate containing macrophages at a MOI of 5. (A) Percentage of phagocytosis. Data are presented as mean $\pm 95 \%$ C.I. ( $n=3$ experiments, ${ }^{* * *} p<0.001$ ). (B) Phagocytic index. (C) CFU counts of $C$. neoformans strains recovered from bone marrow-derived macrophages (BMDMs) after 2 (D) or $24 \mathrm{~h}$ of co-incubation. Error bars represent standard errors of the mean of three biological replicate experiments. The wild-type H99 was used as a control group for statistical comparison. Statistical test: One-way ANOVA with Dunnett's post-test, ${ }^{* *} p<0.01$.

\subsection{Deletion of APN Genes Provokes Minor Effects in the Wax Moth Larva Model of Infection}

In vivo effects of the deletion of $A P N$-like genes in $C$. neoformans virulence were accessed by infection of Galleria mellonella larvae. Infection with both apn $2 \Delta$ and apn1 $\Delta a p n 2 \Delta$ strain resulted in slightly delayed killing kinetics compared to the wild type (Figure S6). The disruption of APN1 did not alter fungal virulence in this model. 


\section{Discussion}

In this work, we examined the role of two BER pathway Apn-like sequences in the proliferation, stress response and virulence of the human pathogen C. neoformans. We identified two genes encoding putative Apurinic/apyrimidinic (AP) endonucleases in this fungus' genome. The CnApn1 (CNAG_05468) predicted protein possesses the nfo domain (Exonuclease IV family), and is consistently different from CnApn2, an Xth family protein (Figure 1B). From the sequences analyzed in this study, only the Apn2 proteins from C. neoformans, S. pombe and H. sapiens possess a zf-GRF domain. The presence of the Athrofin-1 and zf-GRF domains indicates a transcription regulation activity for the deducted proteins $[48,49]$. The absence of this domain in the predicted CnApn1 and in the Apn2 proteins of other fungi suggests that Apn proteins might display distinct roles in DNA repair and cellular responses in yeasts.

C. neoformans (here CnApn2) was previously suggested to be a transcription factor after a screening performed by Jung et al. (2015) [52]. The authors evaluated the presence of DNA sequences associated with transcriptional activity in the $C$. neoformans genome database, detected that the CNAG_04268 null mutant had a growth defect at $39^{\circ} \mathrm{C}$ and further characterized the potential role of this gene as transcription factor [52]. However, the authors did not discuss the homology of the CNAG_04268 deducted protein with DNA repair components, nor did they evaluate the effect of combined disruption of Apn1 and Apn2 in the context of DNA damage-response and survival of $C$. neoformans.

To investigate the potential roles of the predicted AP-endonucleases in the biology of $C$. neoformans, we constructed null mutant strains in which the APN1 and APN2 putative genes were deleted. The deletion of $A P N$-like genes individually or simultaneously indicated that none of the $A P N$ putative genes is essential for $C$. neoformans growth under standard laboratory conditions. The disruption of those genes did not affect the response of C. neoformans to cell wall or membrane stressors (Figure S2). Similar results were previously reported in S. cerevisiae, C. albicans and S. pombe $[19,22,23]$.

In addition, deletion of CnAPN1 and $C n A P N 2$ putative genes did not affect the sensitivity of $C$. neoformans to different sources of oxidative stress $\left(\mathrm{H}_{2} \mathrm{O}_{2}, \mathrm{MND}\right.$ or $\left.\mathrm{NaNO}_{2}\right)$ (Figure 2) as previously observed for $C$. albicans apn1 $1 \Delta$ mutants exposed to $\mathrm{H}_{2} \mathrm{O}_{2}$ [22]. In contrast, the apn $2 \Delta$ mutant was slightly sensitive to $\mathrm{H}_{2} \mathrm{O}_{2}[23,53]$. In $S$. cerevisiae, the simultaneous ablation of the Ntg1, Ntg2, and Apn1 BER proteins resulted in increased recombination and mutation rates but did not influence the response to the oxidizing agents $\mathrm{H}_{2} \mathrm{O}_{2}$ and Menadione [54].

We demonstrated that $C$. neoformans APN deletions induced increased sensitivity to MMS, EMS, MX and UV radiation in a dose-dependent way (Figures 3 and 4). Notably, those agents are known to induce SSB (Single Strand Breaks) and DSB (Double Strand Breaks) on DNA. In contrast, a previous study reported that $C$. albicans BER and NER mutants exhibited a WT sensitivity to EMS and MMS [22,55], suggesting that the BER and NER pathways do not play a major role in repairing DNA breaks in this organism [22,55]. They also observed that $A P N 2$ deletion in S. cerevisiae did not affect its response to MMS-induced damage, but the apn1 $\triangle a p n 2 \Delta$ double mutant displayed a marked increased sensitivity to MMS in comparison to the apn $1 \Delta$ strain $[22,55]$.

In the $S$. pombe BER pathway, mutant strains $n t h 1 \Delta$ and apn $2 \Delta$ were sensitive to MMS while the apn $1 \Delta$ strain was also sensitive to oxidative stress. S. pombe apn $2 \Delta a p n 1 \Delta$ double mutant was more sensitive to the oxidative stress than the apn $2 \Delta$ single mutant [23]. Disruption of APN2 in S. pombe also induced sensitivity to phleomycin, which indicates Apn2 as the major AP-endonuclease of this fungus [23].

We also observed that deletion of the $C$. neoformans APN2-like gene resulted in altered responses to alkylating agents, when compared to the WT and apn1 $\Delta$ strains. The C. neoformans apn $2 \Delta$ strain also presented reduced viability and increased genomic DNA fragmentation after exposure to Zeocin, a Bleomycin family drug (Figure 5). The apn1 $\Delta$ mutant still possesses the APN2 gene and presented the WT-type phenotype in response to Zeocin exposure. Taken together, these data suggest that Apn2 is the major contributor not 
only to the AP-endonuclease but also to the $3^{\prime}$-phosphodiesterase activity in C. neoformans. Curiously, although the Zeocin exposure induced significant death in all mutant strains, it did not provoke DNA fragmentation for the apn1 1 apn $2 \Delta$ double mutant strains. This suggests that the mechanism of death induced by Zeocin may be different for this mutant, not necessarily inducing major DNA fragmentation, such as by accumulation of abasic sites, by blocking RNA transcription and/or by cell cycle arrest.

The differences observed in the BER mutant strains' responses to UV radiation and alkylating agents of $C$. albicans and S. cerevisiae compared to C. neoformans and S. pombe could be associated with the proteins' structure. The human homologues of the yeast Apn proteins are involved in the repair of DSB of DNA [56,57] and HsAPE2 presents a robust $3^{\prime} \rightarrow 5^{\prime}$ exonuclease activity towards mismatched $3^{\prime}$-terminal bases, as well as $3^{\prime}$-phosphoglicolate removal activity [57-59]. The S. pombe Apn2 and the C. neoformans predicted Apn2 protein both present the same zf-GRF domain described as important for the HsAPE2 $3^{\prime}$ exonuclease activity, which is absent in the related proteins of C. albicans and S. cerevisiae, and also in CnApn1 (Figure 1). Our observations suggest that the predicted AP-endonuclease 2 of $C$. neoformans potentially plays a role in additional DNA repair pathways, beyond BER, probably acting in the recognition and correction of SSB and DSB on DNA.

The differences between CnApn1 and CnApn2 sequence domains are probably the reason for the consistent distinct phenotypes of Apn single mutants in response to stress conditions. Apn1 possesses only an AP-endonuclease domain and apn $1 \Delta$ mutants presented, in general, phenotypes similar to the WT strain. Only the dose-dependent response to lower doses of UV radiation and $\mathrm{H}_{2} \mathrm{O}_{2}+\mathrm{MX}$ co-exposure phenotypes were specific for apn $1 \Delta$.

The resistance to lower doses of UV radiation observed in the apn $1 \Delta$ mutant strain could be associated with the reduction of DNA cleavage performed by Apn1. The absence of Apn1 could reduce the cleavage of DNA strands at AP-sites (a UV-radiation induced lesion) and consequently the formation of phosphodiester gaps in DNA strain. This mechanism can be associated with the data observed in Figure 5, when apn $2 \Delta$ mutants presented a WT phenotype in response to $3 \mathrm{mM} \mathrm{H}_{2} \mathrm{O}_{2}+\mathrm{MX}$, a combination that induces base oxidation and AP-sites in DNA. The apn $2 \Delta$ mutant strain still possesses active Apn1 proteins, whose activity could be sufficient to maintain the WT-phenotype in the apn $2 \Delta$ mutant strain.

On the other hand, Apn2 possesses domains involved in biological processes that go beyond DNA repair. The apn $2 \Delta$ strain was more susceptible to UV radiation, alkylation, oxidative and antibiotic stress. Apn2 was also listed as a transcription factor, so it is possible that some of the distinct phenotypes presented by the mutant strain result from the absence of Apn2 transcriptional activity. The apn $1 \Delta a p n 2 \Delta$ double mutant presented similar phenotypes to apn $2 \Delta$, except for the DNA fragmentation pattern and the susceptibility to $\mathrm{H}_{2} \mathrm{O}_{2}$ with $\mathrm{MX}$. The phenotypes observed for double mutants do not always correspond to the absence of individual genes, nor even to a synergic effect of both deletions. Therefore, it is important to note that the apn1 $\triangle a p n 2 \Delta$ mutant may have a specific mechanism of cellular response to stress in order to compensate for the disruption of the cellular APendonuclease activity.

Cryptococcosis affects thousands of people yearly and, although it is important to global health, therapeutic options are extremely limited [60]. We demonstrated that the deletion of the APN2-like gene slightly increased C. neoformans' susceptibility to fluconazole exposure, and that the simultaneous deletion of both predicted APN sequences increased the fungus' sensitivity to AmpB and fluconazole in vitro. We also demonstrated that exposure of $C$. neoformans to the synthetic AP-site inhibitor $\mathrm{MX}$ in combination with AmpB significantly enhanced its antifungal effect, even for the WT strain (Table 2). MX also sensitized cells to the oxidative stress induced by $\mathrm{H}_{2} \mathrm{O}_{2}$ (Figure 5B).

DNA repair-inhibitor drugs, such as $\mathrm{MX}$, are well established in clinical practice as adjuvants [32]. Given the emergence of antifungal drug-resistant strains and the increasing 
incidence of systemic and invasive mycoses [33,61,62], the identification of novel antifungal drug targets and adjuvant options is an urgent clinical need. We demonstrated the synergism between $\mathrm{MX}$ and $\mathrm{AmpB}$, with an increased fungicidal effect on concentrations higher than $75 \mu \mathrm{g} / \mathrm{mL}$ of MX. Although 75 and $150 \mu \mathrm{g} / \mathrm{mL}$ of MX are higher concentrations than those used in clinical trials in cancer therapies $\left(100 \mathrm{mg} / \mathrm{m}^{2}\right.$ or $50 \mathrm{ng} / \mathrm{mL}$ of plasma) [63], our results are still promising. The synergic effect of $M X$ and $A m p B$ is an interesting starting point for further investigations and highlights the possibility of using DNA repair inhibitors as a class of adjuvants in antifungal therapy research.

The deposition of melanin in the cell wall is critical to the virulence of $C$. neoformans and other pathogenic fungi [64-66]. We demonstrated that the disruption of $A P N$-like genes resulted in a delay and significantly lower levels of melanin production by $C$. neoformans (Figure 6) without compromising cell viability or growth rate. Melanin production is activated by oxidative stress conditions in several microorganisms $[65,66]$. In the absence of Apn activity, overlapping enzyme repair systems may be activated later to eliminate the DNA damage accumulation and proceed with melanin synthesis. This might explain the restored melanin production after $144 \mathrm{~h}$ hours in the mutant strains (Figure 6). According to our data, not only the AP-endonuclease activity of Apn proteins, but also the generation/repair of the abasic site itself, might play a role in melanin production by C. neoformans, since the pre-treatment of $C$. neoformans strains with MX for $1 \mathrm{~h}$ had a significant impact on the production of the pigment, even in the WT strain (Figure 7). MX is highly specific and rapidly binds to abasic sites on DNA. The MX-AP-site ligation is strong and stable [67]. Therefore, the phenotype of melanin production blockage is prolonged (10 days), and it is observed even in response to a short time of drug exposure.

C. neoformans is resistant to the host cell's oxidative stress response, mainly due to the production of melanin and antioxidant compounds [37,39]. Several studies have demonstrated a correlation between the capacity of $C$. neoformans clinical strains to be phagocytosed, and/or to proliferate intracellularly, and poor patient outcomes [68-70]. Due to their potential role in melanization, we extended our analysis to evaluate the APNlike mutant's virulence during their interaction with macrophages and G. mellonella larvae. Interestingly, both $C$. neoformans APN-like mutants were less efficiently internalized and more susceptible to killing by M2 macrophages in vitro (Figure 8). The involvement of DNA repair proteins in complex responses, such as interaction with phagocytes, was not exactly expected.

Santiago et al. (2015) used a mutant library screen to list genes involved in macrophage uptake and demonstrated several non-expected genes involved in pathogen-host interaction [51]. One of the listed genes was $A P N 1$, responsible for a decrease in macrophage up-take. However, the mechanism of how individual gene products modulate interactions with host phagocytes is still poorly understood. Since no significant difference was observed in capsule enlargement between apn mutants, other characteristics may be altered in these mutants to influence fungal internalization. We hypothesized the participation of Apn proteins in other cellular mechanisms, beyond DNA repair, as occurs for the mammalian homologue APE1 [17,71]. The impact of Apn proteins' absence on fungal survival inside macrophages may be associated, even in part, with the delay in melanin production, sensitizing the cells to the oxidative stress induced by the phagocyte. This idea can also be the reason for the slight delay in G. mellonella killing by apn $2 \Delta$ and apn $1 \Delta a p n 2 \Delta$ mutant strains (Figure S6), but much is still to be clarified.

\section{Conclusions}

This work demonstrated the impact of AP-endonucleases-like genes in the C. neoformans response to cell stress resistance and virulence. C. neoformans AP endonucleases-like genes were shown to be important in protecting the yeast cells against alkylation and UVinduced damage in vitro. The disruption of $C$. neoformans putative Apn proteins delayed the production of melanin, one of the most important virulence factors in this fungus. The melanin production defect seems to be related to the absence of AP-repair activity, since 
the exposure to $\mathrm{MX}$ completely abolished the pigment production. The MX sensitized C. neoformans to $\mathrm{H}_{2} \mathrm{O}_{2}$ exposure and boosted the fungicidal effect of $\mathrm{AmpB}$, in a synergic way. The Apn-like activities were also required for the interaction and growth inside murine macrophages. This work highlighted the importance of DNA repair pathways for C. neoformans' response to cell stress conditions and the potential use of DNA repair inhibitors to improve the antimicrobial effect of antifungal drugs.

Supplementary Materials: The following are available online at https:/ /www.mdpi.com/2309-608 X/7/2/133/s1, Figure S1: Confirmation of knockout mutants by genomic DNA PCR amplification, Figure S2: Temperature and chemical cell stress-related phenotypes of the C. neoformans APN-like genes' mutants, Figure S3: Growth curve of $C$. neoformans WT and mutant strains, Figure S4: The apn $1 \Delta$, apn $2 \Delta$ and apn $1 \Delta a p n 2 \Delta$ mutants are not susceptible to oxidizing agents, Figure S5: The capsule expansion, phospholipase and urease activities were unaffected by the disruption of Apn-like genes, Figure S6: Evaluation of virulence of $C$. neoformans APN mutants using G. mellonella infection model, Table S1: Primers used in this study and Table S2: Strains used in this study.

Author Contributions: Conceptualization, R.K.d.M.O.; methodology, F.F.F., K.R., R.K.d.M.O., P.H.G. and L.L.P.; validation, R.K.d.M.O., F.A.H. and L.L.P.; formal analysis, R.K.d.M.O.; investigation, R.K.d.M.O. and L.L.P.; resources R.K.d.M.O., F.A.H., P.H.G. and L.L.P., data curation, R.K.d.M.O.; writing—original draft preparation, R.K.d.M.O.; writing—review and editing, R.K.d.M.O., M.J.P.-F., I.S.-P., P.A. and L.F.; supervision, M.J.P.-F., I.S.-P. and L.F.; project administration, R.K.d.M.O., I.S.-P. and L.F.; funding acquisition, I.S.-P. and L.F. All authors have read and agreed to the published version of the manuscript.

Funding: This research was funded by Coordenação de Aperfeiçoamento de Pessoal de Nível Superior (CAPES-Brazil), the National Council for Scientific and Technological Development (CNPq-Brazil; 431958/2016-5) and the "Fundação de Apoio à Pesquisa do Distrito Federal" (FAP-DF, Brazil)/CNPq (PRONEX 0193.001.200/2016). R.K.d.M.O. received a PhD fellowship from the Coordenação de Aperfeiçoamento de Pessoal de Nível Superior (CAPES-Brazil).

Institutional Review Board Statement: The study was conducted according to the national and institutional guidelines for animal care and were approved by the University of Brasilia (UnB) Committee of Ethical Use of Animals (Proc. UnB Doc 52657/2011).

Informed Consent Statement: Not applicable.

Data Availability Statement: The data that support the findings of this study are available from the corresponding authors upon reasonable request.

Acknowledgments: We thank the Molecular Biology and Molecular Pathology Graduate Programs (UnB) for their fellowship support of R.K.d.M.O.; K.R. and F.A.H.

Conflicts of Interest: The authors declare no conflict of interest.

\section{References}

1. Breivik, J.; Gaudernack, G. Resolving the evolutionary paradox of genetic instability: A cost-benefit analysis of DNA repair in changing environments. FEBS Lett. 2004, 563, 7-12. [CrossRef]

2. Rosenberg, S.M. Mutation for survival. Curr. Opin. Genet. Dev. 1997, 7, 829-834. [CrossRef]

3. Dion-Côté, A.-M.; Barbash, D.A. Beyond speciation genes: An overview of genome stability in evolution and speciation. Curr. Opin. Genet. Dev. 2017, 47, 17-23. [CrossRef]

4. Ciccia, A.; Elledge, S.J. The DNA damage response: Making it safe to play with knives. Mol. Cell 2010, 40, 179-204. [CrossRef]

5. Pichiorri, F.; Ishii, H.; Okumura, H.; Trapasso, F.; Wang, Y.; Huebner, K. Molecular parameters of genome instability: Roles of fragile genes at common fragile sites. J. Cell. Biochem. 2008, 104, 1525-1533. [CrossRef] [PubMed]

6. Iyama, T.; Wilson, D.M. DNA repair mechanisms in dividing and non-dividing cells. DNA Repair (Amst). 2013, 12, 620-636. [CrossRef]

7. Friedberg, E.C.; Aguilera, A.; Gellert, M.; Hanawalt, P.C.; Hays, J.B.; Lehmann, A.R.; Lindahl, T.; Lowndes, N.; Sarasin, A.; Wood, R.D. DNA repair: From molecular mechanism to human disease. DNA Repair (Amst). 2006, 5, 986-996. [CrossRef] [PubMed]

8. Krokan, H.E.; Bjørås, M. Base excision repair. Cold Spring Harb. Perspect. Biol. 2013, 5, a012583. [CrossRef]

9. DO, Z. Base Excision DNA Repair. Cell. Mol. Life Sci. 2008, 65. [CrossRef]

10. Schermenhorn, K.M.; Delaney, S.A. Chemical and Kinetic Perspective on Base Excision Repair of DNA. Acc. Chem. Res. 2014, 47. [CrossRef] 
11. Izumi, T.; Hazra, T.K.; Boldogh, I.; Tomkinson, A.E.; Park, M.S.; Ikeda, S.; Mitra, S. Requirement for human AP endonuclease 1 for repair of 3'-blocking damage at DNA single-strand breaks induced by reactive oxygen species. Carcinogenesis 2000, 21, 1329-1334. [CrossRef]

12. Popoff, S.C.; Spira, A.I.; Johnson, A.W.; Demple, B. Yeast structural gene (APN1) for the major apurinic endonuclease: Homology to Escherichia coli endonuclease IV. Proc. Natl. Acad. Sci. 1990, 87, 4193-4197. [CrossRef] [PubMed]

13. Daley, J.M.; Zakaria, C.; Ramotar, D. The endonuclease IV family of apurinic/apyrimidinic endonucleases. Mutat. Res. Mutat. Res. 2010, 705, 217-227. [CrossRef]

14. Demple, B.; Herman, T.; Chen, D.S. Cloning and expression of APE, the cDNA encoding the major human apurinic endonuclease: Definition of a family of DNA repair enzymes. Proc. Natl. Acad. Sci. USA 1991, 88, 11450-11454. [CrossRef]

15. Li, M.; Wilson, D.M. Human apurinic/apyrimidinic endonuclease 1. Antioxid. Redox Signal. 2014, 20, 678-707. [CrossRef]

16. Fleming, A.M.; Ding, Y.; Burrows, C.J. Oxidative DNA damage is epigenetic by regulating gene transcription via base excision repair. Proc. Natl. Acad. Sci. USA 2017, 114, 2604-2609. [CrossRef] [PubMed]

17. Evans, A.R.; Limp-Foster, M.; Kelley, M.R. Going APE over ref-1. Mutat. Res. 2000, 461, 83-108. [CrossRef]

18. Amente, S.; Bertoni, A.; Morano, A.; Lania, L.; Avvedimento, E.V.; Majello, B. LSD1-mediated demethylation of histone H3 lysine 4 triggers Myc-induced transcription. Oncogene 2010, 29, 3691-3702. [CrossRef] [PubMed]

19. Johnson, R.E.; Torres-Ramos, C.A.; Izumi, T.; Mitra, S.; Prakash, S.; Prakash, L. Identification of APN2, the Saccharomyces cerevisiae homolog of the major human AP endonuclease HAP1, and its role in the repair of abasic sites. Genes Dev. 1998, 12, 3137-3143. [CrossRef]

20. Unk, I.; Haracska, L.; Johnson, R.E.; Prakash, S.; Prakash, L. Apurinic endonuclease activity of yeast Apn2 protein. J. Biol. Chem. 2000, 275, 22427-22434. [CrossRef]

21. Bennett, R.A.O. The Saccharomyces cerevisiae ETH1 Gene, an Inducible Homolog of Exonuclease III That Provides Resistance to DNA-Damaging Agents and Limits Spontaneous Mutagenesis. Mol. Cell. Biol. 1999, 19, 1800-1809. [CrossRef]

22. Legrand, M.; Chan, C.L.; Jauert, P.A.; Kirkpatrick, D.T. Analysis of base excision and nucleotide excision repair in Candida albicans. Microbiology 2008, 154, 2446-2456. [CrossRef]

23. Ribar, B.; Izumi, T.; Mitra, S. The major role of human AP-endonuclease homolog Apn2 in repair of abasic sites in Schizosaccharomyces pombe. Nucleic Acids Res. 2004, 32, 115. [CrossRef] [PubMed]

24. Sipiczki, M. Where does fission yeast sit on the tree of life? Genome Biol. 2000, 1, 1-4. [CrossRef]

25. Merlo, D.; Cuchillo-Ibañez, I.; Parlato, R.; Rammes, G. DNA Damage, Neurodegeneration, and Synaptic Plasticity. Neural Plast. 2016, 2016. [CrossRef] [PubMed]

26. Penndorf, D.; Witte, O.W.; Kretz, A. DNA plasticity and damage in amyotrophic lateral sclerosis. Neural Regen. Res. 2018, 13, 173. [CrossRef]

27. Koch, S.C.; Simon, N.; Ebert, C.; Carell, T. Molecular Mechanisms of Xeroderma Pigmentosum (XP) Proteins. Q. Rev. Biophys. 2016, 49. [CrossRef]

28. Machado, C.R.; Menck, C.F.M. Human DNA repair diseases: From genome instability to cancer. Brazilian J. Genet. 1997, 20, 755-762. [CrossRef]

29. Gavande, N.S.; VanderVere-Carozza, P.S.; Hinshaw, H.D.; Jalal, S.I.; Sears, C.R.; Pawelczak, K.S.; Turchi, J.J. DNA repair targeted therapy: The past or future of cancer treatment? Pharmacol. Ther. 2016, 160, 65-83. [CrossRef] [PubMed]

30. Lee, W.; St.Onge, R.P.; Proctor, M.; Flaherty, P.; Jordan, M.I.; Arkin, A.P.; Davis, R.W.; Nislow, C.; Giaever, G.; Friedberg, E.; et al. GenomeWide Requirements for Resistance to Functionally Distinct DNA-Damaging Agents. PLoS Genet. 2005, 1, e24. [CrossRef] [PubMed]

31. Zhang, J.; Stevens, M.F.G.; Bradshaw, T.D. Temozolomide: Mechanisms of Action, Repair and Resistance. Curr. Mol. Pharmacol. 2012, 5. [CrossRef]

32. Liu, L.; Gerson, S.L. Therapeutic impact of methoxyamine: Blocking repair of abasic sites in the base excision repair pathway. Curr. Opin. Investig. Drugs 2004, 5, 623-627.

33. Scorzoni, L.; de Paula E Silva, A.C.A.; Marcos, C.M.; Assato, P.A.; de Melo, W.C.M.A.; de Oliveira, H.C.; Costa-Orlandi, C.B.; Mendes-Giannini, M.J.S.; Fusco-Almeida, A.M. Antifungal Therapy: New Advances in the Understanding and Treatment of Mycosis. Front. Microbiol. 2017, 8, 36. [CrossRef]

34. Belenky, P.; Camacho, D.; Collins, J.J. Fungicidal Drugs Induce a Common Oxidative-Damage Cellular Death Pathway. Cell Rep. 2013, 3, 350-358. [CrossRef] [PubMed]

35. Boiteux, S.; Gellon, L.; Guibourt, N. Repair of 8-oxoguanine in Saccharomyces cerevisiae: Interplay of DNA repair and replication mechanisms. Free Radic. Biol. Med. 2002, 32, 1244-1253. [CrossRef]

36. Missall, T.A.; Lodge, J.K.; McEwen, J.E. Mechanisms of resistance to oxidative and nitrosative stress: Implications for fungal survival in mammalian hosts. Eukaryot. Cell 2004, 3, 835-846. [CrossRef] [PubMed]

37. Magditch, D.A.; Liu, T.-B.; Xue, C.; Idnurm, A.; Park, B.; Wannemuehler, K.; Marston, B.; Govender, N.; Pappas, P. DNA Mutations Mediate Microevolution between Host-Adapted Forms of the Pathogenic Fungus Cryptococcus neoformans. PLoS Pathog. 2012, 8 , e1002936. [CrossRef] [PubMed]

38. Liu, O.W.; Chun, C.D.; Chow, E.D.; Chen, C.; Madhani, H.D.; Noble, S.M. Systematic Genetic Analysis of Virulence in the Human Fungal Pathogen Cryptococcus neoformans. Cell 2008, 135, 174-188. [CrossRef] 
39. Brunke, S.; Seider, K.; Fischer, D.; Jacobsen, I.D.; Kasper, L.; Jablonowski, N.; Wartenberg, A.; Bader, O.; Enache-Angoulvant, A.; Schaller, M.; et al. One Small Step for a Yeast-Microevolution within Macrophages Renders Candida glabrata Hypervirulent Due to a Single Point Mutation. PLoS Pathog. 2014, 10, e1004478. [CrossRef]

40. Esher, S.K.; Zaragoza, O.; Alspaugh, J.A. Cryptococcal pathogenic mechanisms: A dangerous trip from the environment to the brain. Mem. Inst. Oswaldo Cruz 2018, 113. [CrossRef] [PubMed]

41. Rajasingham, R.; Smith, R.M.; Park, B.J.; Jarvis, J.N.; Govender, N.P.; Chiller, T.M.; Denning, D.W.; Loyse, A.; Boulware, D.R. Global Burden of Disease of HIV-associated Cryptococcal Meningitis: An Updated Analysis. Lancet. Infect. Dis. 2017, 17. [CrossRef]

42. Kwon-Chung, K.J.; Fraser, J.A.; Doering, T.L.; Wang, Z.; Janbon, G.; Idnurm, A.; Bahn, Y.-S. Cryptococcus neoformans and Cryptococcus gattii, the Etiologic Agents of Cryptococcosis. Cold Spring Harb. Perspect. Med. 2014, 4. [CrossRef]

43. Kim, M.S.; Kim, S.-Y.; Yoon, J.K.; Lee, Y.-W.; Bahn, Y.-S. An efficient gene-disruption method in Cryptococcus neoformans by double-joint PCR with NAT-split markers. Biochem. Biophys. Res. Commun. 2009, 390, 983-988. [CrossRef]

44. Price, M.F.; Wilkinson, I.D.; Gentry, L.O. Plate Method for Detection of Phospholipase Activity in Candida Albicans. Sabouraudia 1982, 20. [CrossRef]

45. Pfaller, M.A.; Rhomberg, P.R.; Messer, S.A.; Castanheira, M. In vitro activity of a Hos2 deacetylase inhibitor, MGCD290, in combination with echinocandins against echinocandin-resistant Candida species. Diagn. Microbiol. Infect. Dis. 2015, 81, 259-263. [CrossRef]

46. Lutz, M.B.; Kukutsch, N.; Ogilvie, A.L.; Rößner, S.; Koch, F.; Romani, N.; Schuler, G. An advanced culture method for generating large quantities of highly pure dendritic cells from mouse bone marrow. J. Immunol. Methods 1999, 223, 77-92. [CrossRef]

47. García-Rodas, R.; Casadevall, A.; Rodríguez-Tudela, J.L.; Cuenca-Estrella, M.; Zaragoza, O. Cryptococcus neoformans Capsular Enlargement and Cellular Gigantism during Galleria mellonella Infection. PLoS ONE 2011, 6, e24485. [CrossRef] [PubMed]

48. Lu, S.; Wang, J.; Chitsaz, F.; Derbyshire, M.K.; Geer, R.C.; Gonzales, N.R.; Gwadz, M.; Hurwitz, D.I.; Marchler, G.H.; Song, J.S.; et al. CDD/SPARCLE: The conserved domain database in 2020. Nucleic Acids Res. 2020, 48, D265-D268. [CrossRef] [PubMed]

49. Wang, L.; Tsai, C.C. Atrophin proteins: An overview of a new class of nuclear receptor corepressors. Nucl. Recept. Signal. 2008, 6. [CrossRef]

50. Chankova, S.G.; Dimova, E.; Dimitrova, M.; Bryant, P.E. Induction of DNA double-strand breaks by zeocin in Chlamydomonas reinhardtii and the role of increased DNA double-strand breaks rejoining in the formation of an adaptive response. Radiat. Environ. Biophys. 2007, 46, 409-416. [CrossRef] [PubMed]

51. Santiago-Tirado, F.H.; Peng, T.; Yang, M.; Hang, H.C.; Doering, T.L. A Single Protein S-acyl Transferase Acts through Diverse Substrates to Determine Cryptococcal Morphology, Stress Tolerance, and Pathogenic Outcome. PLOS Pathog. 2015, 11, e1004908. [CrossRef]

52. Jung, K.-W.; Yang, D.-H.; Maeng, S.; Lee, K.-T.; So, Y.-S.; Hong, J.; Choi, J.; Byun, H.-J.; Kim, H.; Bang, S.; et al. Systematic functional profiling of transcription factor networks in Cryptococcus neoformans. Nat. Commun. 2015, 6, 6757. [CrossRef] [PubMed]

53. Osman, F.; Bjørås, M.; Alseth, I.; Morland, I.; McCready, S.; Seeberg, E.; Tsaneva, I. A new Schizosaccharomyces pombe base excision repair mutant, nth1, reveals overlapping pathways for repair of DNA base damage. Mol. Microbiol. 2003, 48, 465-480. [CrossRef]

54. Swanson, R.L.; Morey, N.J.; Doetsch, P.W.; Jinks-Robertson, S. Overlapping specificities of base excision repair, nucleotide excision repair, recombination, and translesion synthesis pathways for DNA base damage in Saccharomyces cerevisiae. Mol. Cell. Biol. 1999, 19, 2929-2935. [CrossRef]

55. Legrand, M.; Chan, C.L.; Jauert, P.A.; Kirkpatrick, D.T. Role of DNA Mismatch Repair and Double-Strand Break Repair in Genome Stability and Antifungal Drug Resistance in Candida albicans. Eukaryot. Cell 2007, 6, 2194-2205. [CrossRef] [PubMed]

56. Schrader, C.E.; Guikema, J.E.; Wu, X.; Stavnezer, J. The roles of APE1, APE2, DNA polymerase $\beta$ and mismatch repair in creating S region DNA breaks during antibody class switch. Philos. Trans. R. Soc. B Biol. Sci. 2009, 364, 645-652. [CrossRef] [PubMed]

57. Burkovics, P.; Szukacsov, V.; Unk, I.; Haracska, L. Human Ape2 protein has a 3'-5' exonuclease activity that acts preferentially on mismatched base pairs. Nucleic Acids Res. 2006, 34, 2508-2515. [CrossRef]

58. Hossain, M.A.; Lin, Y.; Yan, S. Single-Strand Break End Resection in Genome Integrity: Mechanism and Regulation by APE2. Int. J. Mol. Sci. 2018, 19, 2389. [CrossRef] [PubMed]

59. Hadi, M.Z.; Ginalski, K.; Nguyen, L.H.; Wilson, D.M. Determinants in nuclease specificity of ape1 and ape2, human homologues of Escherichia coli exonuclease III. J. Mol. Biol. 2002, 316, 853-866. [CrossRef]

60. Mourad, A.; Perfect, J.R.; Mourad, A.; Perfect, J.R. The war on cryptococcosis: A Review of the antifungal arsenal. Mem. Inst. Oswaldo Cruz 2018, 113. [CrossRef]

61. Kwon-Chung, K.J.; Chang, Y.C. Aneuploidy and Drug Resistance in Pathogenic Fungi. PLoS Pathog. 2012, 8, e1003022. [CrossRef]

62. Altamirano, S.; Fang, D.; Simmons, C.; Sridhar, S.; Wu, P.; Sanyal, K.; Kozubowski, L. Fluconazole-Induced Ploidy Change in Cryptococcus neoformans Results from the Uncoupling of Cell Growth and Nuclear Division. mSphere 2017, 2. [CrossRef] [PubMed]

63. Weiss, G.J.; Gordon, M.S.; Rosen, L.S.; Savvides, P.; Adams, B.J.; Alvarez, D.; Liu, L.; Xu, Y.; Gerson, S.L.; Leigh, B.R. Final results from a phase I study of oral TRC102 (methoxyamine $\mathrm{HCl}$ ), an inhibitor of base-excision repair, to potentiate the activity of pemetrexed in patients with refractory cancer. J. Clin. Oncol. 2010, 28, 2576. [CrossRef]

64. Casadevall, A. Determinants of virulence in the pathogenic fungi. Fungal Biol. Rev. 2007, 21, 130. [CrossRef]

65. Gomez, B.L.; Nosanchuk, J.D. Melanin and Fungi. Curr. Opin. Infect. Dis. 2003, 16. [CrossRef] [PubMed]

66. Nosanchuk, J.D.; Stark, R.E.; Casadevall, A. Fungal Melanin: What do We Know About Structure? Front. Microbiol. 2015, 6, 1463. [CrossRef] 
67. Gurkan-Cavusoglu, E.; Avadhani, S.; Liu, L.; Kinsella, T.J.; Loparo, K.A. Developing an in silico model of the modulation of base excision repair using methoxyamine for more targeted cancer therapeutics. IET Syst. Biol. 2013, 7, 27-37. [CrossRef] [PubMed]

68. Sabiiti, W.; May, R.C. Mechanisms of infection by the human fungal pathogen Cryptococcus neoformans. Future Microbiol. 2012, 7, 1297-1313. [CrossRef]

69. Sabiiti, W.; Robertson, E.; Beale, M.A.; Johnston, S.A.; Brouwer, A.E.; Loyse, A.; Jarvis, J.N.; Gilbert, A.S.; Fisher, M.C.; Harrison, T.S.; et al. Efficient phagocytosis and laccase activity affect the outcome of HIV-associated cryptococcosis. J. Clin. Invest. 2014, 124, 2000-2008. [CrossRef]

70. Alanio, A.; Desnos-Ollivier, M.; Dromer, F. Dynamics of Cryptococcus neoformans-macrophage interactions reveal that fungal background influences outcome during cryptococcal meningoencephalitis in humans. MBio 2011, 2, e00158-11. [CrossRef]

71. Tell, G.; Quadrifoglio, F.; Tiribelli, C.; Kelley, M.R. The many functions of APE1/Ref-1: Not only a DNA repair enzyme. Antioxid. Redox Signal. 2009, 11, 601-620. [CrossRef] [PubMed] 